\title{
Öğretmenlerin Kendini İșe Verememe Nedenleri Üzerine Fenomenolojik Bir Çözümleme ${ }^{1}$
}

\author{
Akif KÖSE \\ Dr. Öğr. Üyesi, Kahramanmaraş Sütçü İmam Üniversitesi, \\ Eğitim Fakültesi, Eğitim Bilimleri Bölümü, Eğitim Yönetimi Ana Bilim Dalı \\ akifkose@ksu.edu.tr \\ Orcid ID: https://orcid.org/0000-0002-6961-6052 \\ Mehmet UZUN \\ Uzman, Kahramanmaraş Sütçü İmam Üniversitesi, \\ Sosyal Bilimler Enstitüsü, Eğitim Yönetimi Ana Bilim Dalı Doktora Öğrencisi \\ mehmetuzun461@hotmail.com \\ Orcid ID: https://orcid.org/0000-0003-2786-5533
}

\section{$\ddot{O} \mathbf{z}$}

$\mathrm{Bu}$ araştırmanın amacı öğretmenlerin kendini işe verememe nedenlerine ilişkin öğretmen görüşlerinin belirlenmesidir. Araştırma nitel bir çalışma olup olgubilim deseninde gerçekleştirilmiştir. 2019-2020 Eğitim Öğretim Yılında Kahramanmaraş il merkezinde farklı kademelerde görev yapan 34 öğretmen araştırma örneklemi olarak belirlenmiş, görüşme yoluyla katılımcılardan elde edilen veriler içerik analize tabi tutulmuştur. Araştırma sonucunda öğretmenlerin kendini işe verememelerine kaynaklık eden nedenlerin 9 tema altında toplandığ 1 , bu temaların ise mesleki bağlılık ve mesleki tutumla ilgili nedenler; ailevi nedenler; içinde bulunulan ekonomik durum ve mesleğin gelir düzeyi ile ilgili nedenler; ülkedeki siyasal/politik gelişmelerle ilgili nedenler; görev yapılan yerin sosyokültürel ve sosyoekonomik özellikleriyle ilgili nedenler; toplumun eğitime/öğretmene bakışıyla ilgili nedenler; sosyal medya ve diğer iletişim araçlarındaki yayınlarla ilgili nedenler; okul paydaşlarıyla (merkez ve taşra yönetimi, okul idarecileri, kurum öğretmenleri, öğrenciler, veliler ve diğer personel) ilgili nedenler olduğu ortaya çıkmıştır. Temalar altında yer alan nedenlerin detaylı bir biçimde içerisinde sunulduğu bu araştırmanın son kısmında ise uygulayıcılara ve araştırmacılara dönük öneriler getirilmiştir.

\footnotetext{
${ }^{1}$ Makale Geliş/Kabul Tarihi: 07.04.2020 / 28.08.2020

Künye Bilgisi: Köse, A. ve Uzun, M. (2020). Ögretmenlerin Kendini İşe Verememe Nedenleri Üzerine Fenomenolojik Bir Çözümleme. Kahramanmaraş Sütçü İmam Üniversitesi Sosyal Bilimler Dergisi, 17 (2), 680-728. DOI: 10.33437/ksusbd.716213
} 
Anahtar Kelimeler: Öğretmen, Kendini İşe Verme, Kendini İşe Verememe Nedenleri.

\title{
A Phenomenological Analysis on the Reasons for Teachers' Failure in Work Engagement
}

\begin{abstract}
This research attempts to determine teachers' views regarding the reasons for teachers' failure in work engagement. Having a qualitative research design, the research utilized a phenomenological design. The research sample consisted of 34 teachers working at different levels in the city centre of Kahramanmaraş during 2019-2020 academic year. The data were obtained through interviews and content analysis was used during data analysis. The research findings revealed that the reasons causing the teachers' failure in work engagement were gathered under 9 themes. These were identified as the reasons related to occupational commitment and occupational attitude; family-related reasons; the reasons related to the current economic situation and income level of the occupation; the reasons related to the political developments in the country; the reasons related to the sociocultural and socioeconomic characteristics of the place where teachers work; the reasons related to the society's view towards education / teacher; reasons related to the news in social media and other communication tools; reasons related to school stakeholders (central and provincial management, school administrators, teachers, students, parents and other staff). Based upon the findings, various recommendations were provided for practitioners and researchers.
\end{abstract}

Keywords: Teacher, Work Engagement, Reasons for Failure in Work Engagement.

\section{GİRIŞ}

İş görenlerin, çalıştıkları örgütlerinden birtakım beklentilerinin olduğu gibi örgütlerin de iş görenlerinden belirli beklentileri vardır. Örgütlerin iş görenlerinden genel manada beklentilerinin; iş görenlerin mental, fiziksel ve duygusal yönden enerjilerini örgütsel amaçlar doğrultusunda harcamaya istekli olmaları ve bu enerjilerini örgütsel amaçları gerçekleştirmek için harcamaları yani kendilerini işe vermeleridir. İş görenlerden beklenen kendini işe verme 
davranışı ise bireysel ve örgütsel birçok bileşenin etkisiyle ve etkileşimiyle ortaya çıkan bir durumdur. Örgütler, yaşamlarını devam ettirebilmek için örgüt açısından bu istendik durumu ortaya çıkaracak bileşenleri bir bütün olarak değerlendirip, bu yönde stratejiler geliştirmek durumundadırlar.

Gerek örgütler gerekse iş görenler açısından pozitif sonuçlar doğuran kendini işe verme davranışı üzerinde örgütsel faktörlerin belirli bir etkiye sahip olduğu bilinmektedir. Ancak, iş gören yaşamının örgüt dışında da devam ettiği, örgüt dışında da iş görenlerin birçok formal ya da informal grupların üyesi oldukları, aile içerisinde ya da sosyal çevresinde birtakım rollerinin ve sorumluluklarının bulunduğu gerçeği, kendini işe verme davranışının sadece örgütsel faktörlerle açıklanamayacağını da göstermektedir. Dolayısıyla iş görenlerde kendini işe verme davranışının sağlanmasında örgüt içi ve örgüt dışı şartların bir bütün olarak ele alınması gerektiği gerçeği ortaya çıkmaktadır.

İçsel tatmin ve adanmayı da içeren bir kavram olan kendini işe verme; (Mustosmäki, Anttila ve Oinas, 2013: 64) dinçlik, adanmışlık ve yoğunlaşma boyutlarından oluşan işle ilgili, pozitif ve tatmin edici bir zihin durumu olarak tanımlanmaktadır (Schaufeli, Salanova, Gonzalez-Roma ve Bakker, 2002). Schaufeli (2012) bu tanımlamadaki dinçliği, bireyin işindeyken enerjisini ve zihinsel direncini yüksek seviyede tutması, işinde çaba gösterme istekliliği ve bu istekliliğin en karmaşık durumlarda bile sürekliliğini devam ettirmesi; adanmayl, kişinin işiyle fazlasıyla alakadar olması, işine önem göstermesi ve işinde heyecan, ilham, gurur ve mücadele duygularını hissetmesi; yoğunlaşmayı ise kişinin tamamen işine motive olması, huzurlu bir şekilde işiyle meşgul olması bu sayede de zamanının hızla geçmesi ve işten kendini alıkoyamaması şeklinde ifade etmektedir. Kendini işe verme, bu boyutlarıla iş görenlerin işlerine yoğun bir enerjiyle yaklaşıp, adanmışılık içerisinde işleriyle bütünleştikleri bir yapıyı işaret ederken (Gündüz, Çapri ve Gökçakan, 2013: 30) kimi yazarlara göre tükenmişlik madalyonunun diğer yüzü olarak da değerlendirilmektedir (Ardıç ve Polatcı, 2009: 25).

Pozitif örgütsel davranış olan ve kavramsal olarak 21. yy. başlarında ortaya konulan kendini işe verme, yönetim literatüründe job/work/employee engagement şeklinde ifade edilmektedir (Özkalp ve Meydan, 2015: 5). Kavramın ulusal yazında ise işe adanma, işe gönülden adanma, işe adanmışlık, işle bütünleşme, çalışmaya tutkunluk, işe bağl1lık, işe bağlanma, işe cezbolma, işe tutkunluk, işe angaje olma, kendini işe verme, çalışan bağ l1lı̆̆ 1 , işe yoğunlaşma, iş tutulması ve işe kapılma şeklindeki kullanımlarına da rastlanılmaktadır (Uzun, 2019: 41).

Kavram olarak ulusal yazında farklı kullanımları bulunan kendini işe verme, birçok bireysel ve örgütsel kazanıma da kaynaklık etmektedir. Anlamlı iş 
çıktılarının oluşmasına katkı sağlayan (Harter, Schmidt ve Hayes, 2002: 276) kendini işe verme davranışıyla ilgili yapılmış olan araştırmalar, bu davranışı sergileyen iş görenlerin, örgütlerinin kendilerine sağlamış olduğu kaynakların karşıllğını verme eğiliminde olduklarını ve örgütlerine daha güçlü sadakat geliştirdiklerini göstermektedir (Agyemang ve Ofei, 2013; Hakanen, Bakker ve Schaufeli, 2006; Saks, 2006). Saks (2006: 604) kendini işe vermenin, iş görenlerdeki iş tatminini, örgütsel bağlılığı ve örgütsel vatandaşlık davranışlarını arttırdığını, çalışanların işten ayrılma niyetlerini azalttığını belirtmektedir. Bunun yanı sıra kendini işe verme üzerine yapılan araştırmalar kendini işe vermenin yüksek seviyede örgütsel sorumluluğa, artmış iş memnuniyetine, daha az devamsızlık ve iş hacmi oranlarına, iyileştirilmiş sağlık ve iyi olma haline, daha fazla rol davranışlara, yüksek performansa, kişisel teşebbüste yüksek arza, önleyici tedbirler alan davranışlara ve öğrenme motivasyonuna katkı sunduğunu göstermiştir (Schaufeli ve Salanova, 2007).

Yukarıda ifade edilen tüm bu olumlu yönler, örgütlerin, iş görenlerinin kendini işe vermelerini önemsemeleri gerektiğini göstermektedir. Bu bakımdan kendini işe verme davranışının öncüllerin bilinmesi günümüzde örgütler açısından daha fazla önem kazanmış bir zorunluluktur. Bir diğer ifadeyle, ancak bu öncüllerin neler olduğunu bilen örgütler, iş görenlerin kendini işe vermelerini sağlayabileceklerdir. Bu durum ile ilgili olarak Wollard ve Shuck (2011: 433) geniş kapsamlı bir araştırma yaparak kendini işe vermeye yönelik deneysel ve kuramsal araştırmaları incelemişler ve kendini işe vermenin pek çok bireysel ve örgütsel öncülünün bulunduğunu ortaya koymuşlardır.

İş görenlerin bireysel özelliklerinden kaynaklanan ve iş rollerinin kendilerine yüklediği sorumlulukları yerine getirebilmelerine yardımcı olan bireysel öncüller, iş görenlerin çevrelerini etkili bir şekilde kontrol edebilme ve etkileyebilme yeteneklerini yansıtmaktadır. Bu bireysel öncüller ayrıca iş görenlerin örgütte kariyer başarısını yakalamalarını sağlarken kendini işe vermeleri üzerinde de pozitif ve önemli bir etki oluşturmaktadır (Şahinbaş, 2018: 35-36). İş görenlerin kendini işe vermelerinde etkili olan örgütsel öncüller ise örgüt iklimi, örgüt kültürü, ücret, çalışma şartları, iş görenlerin gelişimine sunulan destek, örgütün iş görenleri güdülemek için kullandığı motivasyon araçları, yöneticilerin yöneticilik ve liderlik uygulamaları, meslektaş davranışları ve bu faktörlerin dışında sayılabilecek etken konumundaki birçok öncüldür. Maslach ve Leiter (1997), bireyin iş çevresinde yer alan iş yükü, kontrol, ödül, aidiyet, adalet ve değerlerden oluşan altı değişkeni çalışma hayatı alanları olarak tanımlamışlardır. $\mathrm{Bu}$ alanlarla ilgili oluşabilecek birey ve iş arasındaki uyumsuzluk tükenmişliğe, uyum ise kendini işe vermeye neden olacaktır (Ardıç ve Polatç1, 2009: 25). Saks (2006: 604), Kahn'ın yaklaşımından yola çıkarak yapmış olduğu araştırma sonucunda iş karakteristikleri, algılanan örgütsel destek, 
algılanan yönetici desteği, ödül ve tanınma, işlemsel adalet ve dağıtımsal adaleti, kendini işe vermeyi etkileyen örgütsel faktörler olarak belirlemiştir.

Yapılan araştırmalar kendini işe vermeyi etkileyen birçok bireysel ve örgütsel faktörlerin varlığını işaret etmekte ve bu faktörler bireyden bireye, örgütten örgüte (Demerouti, Bakker, Nachreiner ve Schaufeli, 2001) değişkenlik gösterebilmektedir. Ancak, örgütler hangi farklı özelliklere sahip olursa olsunlar iş görenlerin kendini işe verme davranışlarını engelleyen etmenler konusu tüm örgütler için üzerinde durulması gereken önemli bir problem olarak ortaya çıkmaktadır. İşgörenlerin kendini işe vermelerini engelleyen nedenlerin varlı̆g 1 şüphesiz her örgüt için tehdit oluşturmaktadır. İnsan unsurunun her yönüyle en yaygın biçimde yer aldığı eğitim örgütlerinde bu nedenler daha da önemli bir hal almaktadır. Çünkü eğitim örgütü dışındaki birçok örgütte iş görenin kendini işe verememe durumunun doğurduğu sonuçları saptamak, bununla ilgili çözüm önerileri geliştirmek ve problem durumunu ortadan kaldırmak daha kolay ve kısa vadede mümkün olabilmektedir. Ancak, eğitim örgütlerinde kendini işe verememenin doğurduğu sonuçların daha uzun vadede ortaya çıkmasından dolayı bu duruma kaynaklık teşkil eden iş görenler ve iş gören davranışları hakkında kesin bir bilgiye ulaşmak çok daha zordur. Bu bakımdan ürettiği hizmetin sonuçları uzun vadede alınan eğitim örgütleri, iş görenlerin kendini işe verebilmeleri için gerekli şartları süreç içerisinde oluşturmalı, iş görenlerin bu durumlarını yine süreç içerisinde sürekli olarak kontrol etmeli, varsa müdahale edilmesi gereken noktalarda gerekli önlemleri gecikmeden almalıdırlar. Aksi durumda eğitim örgütlerinin, eğitsel açıdan telafisi mümkün olmayan sonuçlarla karşılaşmaları kaçınılmaz olacaktır.

Eğitim örgütlerinin sosyal, ekonomik ve politik amaçları okullarda ve büyük ölçüde öğretmenler aracılığıyla gerçekleştirilmektedir. Bu durum eğitim ve öğretim faaliyetlerinde ana unsur olan öğretmenlerin kendini işe verme davranışlarının önemini ön plana çıkarmaktadır. Öğretmenlerde bu davranışın varlığı ve düzeyi başta öğrenciler olmak üzere okul örgütünden beklentisi olan kişi, grup ve kurumları doğrudan ve/veya dolaylı etkilemektedir. Bu bakımdan öğretmenlerin kendini işe verememelerinin nedenlerinin tüm yönleriyle belirlenmesi eğitimin tüm paydaşları açısından gerekli olan bir durum olarak değerlendirilmektedir. Bu araştırma kapsamında ulaşılabilen alan yazınla sınırlı olmak üzere incelenen çalışmalar içerisinde öğretmenlerin kendini işe verememe nedenlerine odaklanan herhangi bir çalışılmaya rastlanılamamıştır. Bu bakımdan öğretmenlerin kendini işe verememe nedenlerini ortaya çıkarmayı amaçlayan bu araştırmanın başta alan yazın olmak üzere politika yapıcılara, uygulayıcı konumda olan eğitim yöneticileri ile öğretmenlere ve okulların diğer bütün paydaşlarına katkı sağlayacağı düşünülmektedir. Bu noktadan hareketle araştırmanın problem cümlesi "Öğretmenlerin kendini işe verememe nedenlerine yönelik öğretmen görüşleri nelerdir?"şeklinde ifade edilebilir. 


\section{Araştırmanın Amacı}

$\mathrm{Bu}$ araştırmada, görüşlerine başvurulan öğretmenlerin kendini işe veremeyişleri ve bunun sebeplerine değil de genel manada bir öğretmenin kendini işe verememesinin nedenlerinin neler olabileceğine odaklanılmıştır. $\mathrm{Bu}$ bağlamda araştırmanın genel amacı; öğretmenlerin kendini işe verememe nedenlerine yönelik öğretmen görüşlerini belirlemektir. Bu genel amaç doğrultusunda aşağıdaki sorulara yanıt aranmıştır:

Öğretmenlerin kendini işe verememelerinin;

1. Mesleki bağl1lık ve mesleki tutumla ilgili nedenlerine yönelik öğretmen görüşleri nelerdir?

2. Ailevi nedenlerine yönelik öğretmen görüşleri nelerdir?

3. İçinde bulunulan ekonomik durum ve mesleğin gelir düzeyi ile ilgili nedenlerine yönelik öğretmen görüşleri nelerdir?

4. Ülkedeki siyasal/politik gelişmelerle ilgili nedenlerine yönelik öğretmen görüşleri nelerdir?

5. Görev yapılan yerin sosyokültürel ve sosyoekonomik özellikleriyle ilgili nedenlerine yönelik öğretmen görüssleri nelerdir?

6. Toplumun eğitime/öğretmene bakışıyla ilgili nedenlerine yönelik öğretmen görüşleri nelerdir?

7. Sosyal medya ve diğer iletişim araçlarındaki yayınlarla ilgili nedenlerine yönelik görüşleri nelerdir?

8. Okul paydaşlarıyla ilgili nedenlerine yönelik öğretmen görüşleri nelerdir?

9. Yukarıda ifade edilen nedenlerin dışındaki diğer nedenlerine yönelik öğretmen görüşleri nelerdir?

\section{YÖNTEM}

Bu bölümde araştırmanın modeli, araştırma örneklemi, veri toplama araçları, verilerin toplanması ve analizi, geçerlik ve güvenirlik ile ilgili bilgilere yer verilmiştir.

\section{Araştırmanın Modeli}

Öğretmenlerin kendini işe verememe nedenlerine yönelik öğretmen görüşlerinin belirlemesinin amaçlandığ bu araştırma nitel bir çalışma olup 
olgubilim deseninde gerçekleştirilmiştir. Olgubilim deseni farkında olduğumuz ancak derinlemesine ve ayrıntılı bir anlayışa sahip olmadığımız olgulara odaklanmaktadır. Olgubilim deseni bize tümüyle yabancı olmayan aynı zamanda da tam anlamıyla kavrayamadığımız olguları araştırmayı amaçlayan çalışmalar için uygun bir araştırma zemini oluşturur (Yıldırım ve Şimşek, 2011). Bu bakımdan araştırmanın olgubilim deseninde gerçekleştirilmesinin uygun olduğu görülmüş, "öğretmenlerin kendini işe verememe nedenleri" bu araştırmanın olgusu olarak ele alınmıştır.

\section{Örneklem}

Araştırmanın örneklemini 2019-2020 Eğitim Öğretim Y1lında Kahramanmaraş İl Milli Eğitim Müdürlüğü'ne bağlı kamu okullarında (anaokulu, ilkokul, ortaokul ve lise) görevli ve amaçlı örnekleme yöntemlerinden maksimum çeşitlilik örnekleme yöntemiyle seçilen 34 öğretmen oluşturmaktadır. Maksimum örnekleme yapmadaki amaç göreli olarak küçük bir örneklem oluşturarak araştırma probleminin bir parçası konumunda olan bireylerin çeşitliliğini yüksek oranda yansıtmaktır (Yıldırım ve Şimşek, 2011). Bu amaçla tüm öğretim kademelerinden öğretmenler seçilerek araştırma örneklemine dâhil edilmişlerdir. Araştırma örneklemine dâhil edilen öğretmenlerin \%53'ünü $(n=18)$ erkekler, $\% 47$ 'sini $(\mathrm{n}=16)$ kadınlar oluşturmaktadır. Öğretmenlerin \%59'u $(\mathrm{n}=20)$ lisans mezunu iken, \%41'i $(n=14)$ lisansüstü mezunudur. Öğretmenlerin \%23,5'i $(n=8)$ anaokullarında, $\% 29,5^{\prime} \mathrm{i}(\mathrm{n}=10)$ ilkokullarda, $\% 23,5$ ' $\mathrm{i}(\mathrm{n}=8)$ ortaokullarda ve $\% 23,5$ 'i de $(n=8)$ liselerde görev yapmaktadır.

\section{Veri Toplama Araçları}

Araştırmanın verileri görüşme tekniklerinden yarı yapılandırılmış görüşme tekniği ile ve yarı yapılandırılmış görüşme formu aracılığıyla toplanmıştır. Araştırmacılar tarafından hazırlanan yarı yapılandırılmış görüşme formunda katılımc1lara "1. Öğretmenlerin kendini işe verememelerine neden olan mesleki nedenlere yönelik görüşleriniz nelerdir? şeklinde açık uçlu 9 soru yöneltilmiştir. $\mathrm{Bu}$ sorular araştırmacılar tarafından alan yazın taraması yapılarak ayrıca alan uzmanı bir akademisyenin görüşüne başvurularak oluşturulmuştur. Görüşme formlarının asıl uygulamasına geçmeden önce beş katılımcı ile pilot uygulama yapılmıştır. Yapılan pilot uygulama sonucunda soruların veri toplama amacına uygun nitelikte olduğu görülmüştür. Pilot uygulama kapsamında yapılan görüşmelerden elde edilen veriler asıl uygulamadan elde edilen veriler ile birlikte değerlendirilmiştir.

\section{Verilerin Toplanması ve Analizi}

Araştırma kapsamında hazırlanmış olan veri toplama araçlarının etik açıdan uygunluğuna ilişkin Kahramanmaraş Sütçü İmam Üniversitesi Sosyal ve Beşerî 
Bilimler Etik Kurulunun23.03.2020 tarihli ve 2020/7 say1lı karar1 ile etik kurul onayı alınmıştır. Görüşme formlarının Kahramanmaraş İl Milli Eğitim Müdürlüğ̈̈ne bağlı kamu okullarında uygulanabilmesi için ayse.meb.gov.tr üzerinden araştırma uygulama izni ön başvurusu yapılmış, ardından araştırma izni için gerekli evraklar sunularak Kahramanmaraş İl Milli Eğitim Müdürlüğünden araştırma izni alınmıştır. Öğretmenlerle yapılan görüşmelerden elde edilen veriler elektronik ortama aktarılmıştır. Araştırmanın örneklemini oluşturan öğretmenlere Ö1'den başlayarak Ö34'e kadar isimler verilmiştir. Görüşmelerden elde edilen veriler önce kavramsallaştırılmış daha sonra ortaya çıkan kavramlara göre mantıklı bir şekilde düzenlenerek veriyi açıklayan temaların saptanmasını gerektiren içerik analizi yöntemi kullanılmıştır (Yıldırım ve Şimşek, 2011). Araştırmada elde edilen verilerin araştırmacılar tarafından ayrı ayrı okunarak kodlama işlemleri yapılmış, araştırmacılar tarafindan tekrar okuma yapılmış ve sonrasında bazı veri kısımlarını kodlamak için kullanılan kavramlar değiştirilmiştir. Oluşan kodların temaları belirlenmiştir. Bu aşamadan sonra araştırmacılar tarafindan oluşturulan bütün kodlamalar ve temalar karşılaştırılmış, kodların ve temaların ne olacağına dair son karar verildikten sonra frekans tabloları oluşturulmuştur.

\section{Geçerlik ve Güvenirlik}

Araştırmanın yöntemi ve araştırma sürecinde takip edilen aşamalar araştırma raporunda açık bir şekilde izah edilmeye çalışılmış, araştırmanın ham verileri araştırmacılar tarafından muhafaza altına alınmış böylece araştırmanın dış güvenirliği arttırılmaya çalışılmıştır. Araştırma soruları açıkça ifade edilmiş, veriler araştırma soruları çerçevesinde ayrıntılı ve amaca uygun olarak toplanmaya çalışılmış, araştırma verileri biri alan uzmanı akademisyen olmak üzere araştırmacıların her ikisi tarafından da ayrı ayrı kodlanıp kodlamalar arasındaki uyum yüzdesine bakılmıştır. Gerçekleştirilen bu hususlarla da araştırmanın iç güvenirliği sağlanmaya çalışılmıştır (Yıldırım ve Şimşek, 2011). Araştırmacılar tarafından araştırmanın bütün verileri üzerinde ayrı ayrı yapılan kodlamalar birbirleri ile karşılaştırılarak kodlamalar arasındaki tutarlılık incelenmiş, elde edilen kodların birbirine benzer ve uyumlu olduğu görülmüştür. Araştırmacıların yaptığı kodlamalardan elde edilen toplam kod sayıları iki ayrı araştırmacı için sırasıyla 243 ve 169 olarak belirlenmiştir. Araştırmacıların yaptıkları kodlamalar arasındaki uyumun yüzdesini belirlemek için şu formülasyon kullanılmıştır (Emmer ve Millett, 1970; Akt. Selçuk, 2001): Yüzdelik Uyum=100×[1-(A-B):(A+B)] $=100 \times[1-(243-169):(243+169)]=\% 83$

Kodlamalar arasındaki uyumun $\% 75$ ve üzeri olması gerektiği (Emmer ve Millett, 1970; Akt. Selçuk, 2001) dikkate alındığında iki ayrı kodlama arasındaki uyum düzeyinin \%83 olmasının kodlamalar arasındaki tutarlılığa işaret ettiği, bir diğer ifadeyle kodlamaların güvenilir olduğu görülmüştür. Araştırmada doğrudan 
alıntılar yapılarak katılımcı görüşlerine yer verilmiş olması ve araştırma bulgularının kendi içinde tutarlılık göstermiş olması hususları araştırmanın geçerliğini arttıran unsurlar olduğu değerlendirilmiştir.

\section{BULGULAR}

Öğretmenlerin Kendini İşe Verememelerinin Mesleki Bağlılık ve Mesleki Tutumla İlgili Nedenleri

Öğretmenlerin kendini işe verememelerinin mesleki bağlılıkları ve mesleki tutumları ile ilgili nedenlerine ilişkin görüşlerinin analizi sonucu elde edilen temalar ve bu temalara ilişkin kodlar Tablo 1'de verilmiştir.

Tablo 1.Öğretmenlerin Kendini İşe Verememelerinin Mesleki Bağlılık ve Mesleki Tutumla ile İlgili Nedenleri

\begin{tabular}{|c|c|c|c|}
\hline & & & Frekans \\
\hline & & Öğretmenlik mesleğini sevmeme & 7 \\
\hline & & Yanlıș meslek seçmiș olma & 5 \\
\hline & & Mesleğini maddi kaygıllardan ötürü yapma & 5 \\
\hline$\stackrel{\bar{\partial}}{\Xi}$ & & Üniversite puanının öğretmenliğe yetmiş olması & 5 \\
\hline$\frac{\bar{\theta}}{8}$ & & Öğretmenliğe bağlılığının olmaması & 2 \\
\hline$z$ & & Meslekte başarısız olduğuna inanma & 2 \\
\hline & Kişisel & Motivasyon düşüklüğü yaşama & 1 \\
\hline . & & Öğretmenliği zorunluluktan dolayı yapma & 1 \\
\hline$\stackrel{9}{=}$ & & Öğretmenlik mesleğini tanımadan seçmiş olma & 1 \\
\hline 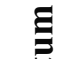 & & Öğretmenliğin, kendi beklentilerini & \\
\hline$\equiv$ & & karşılayamaması & 1 \\
\hline 5 & & Mesleğin yıpratıcı olduğunu düşünme & 1 \\
\hline e & & Çalışma saatlerinin istediği gibi olmaması & 1 \\
\hline$\underbrace{2}$ & & Toplam & 32 \\
\hline$\sum_{i}^{\infty}$ & Meslektaş, & $\begin{array}{lllll}\begin{array}{l}\text { Meslektaşların } \\
\text { davranısları }\end{array} & \text { motivasyon } & \text { kırıcı } & \text { tutum } & \text { ve }\end{array}$ & 1 \\
\hline 兰 & Okul ve & Yönetim kaynaklı değersizlik duygusu yaşama & 1 \\
\hline$\overline{10}$ & $\begin{array}{l}\text { Ust } \\
\text { Vönotim }\end{array}$ & Başarıların ödüllendirilmemesi & 1 \\
\hline 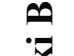 & Yönetim & Üst makamların olumsuz tutum ve davranıșları & 1 \\
\hline$\frac{\frac{\pi}{0}}{\frac{0}{2}}$ & $\begin{array}{l}\text { Kaynakl1 } \\
\text { Nedenler }\end{array}$ & $\begin{array}{l}\text { İdealist öğretmenlerin süreçte yaşadıkları hayal } \\
\text { kırıklıkları }\end{array}$ & 1 \\
\hline & & $\begin{array}{ll} & \text { Toplam } \\
\end{array}$ & 5 \\
\hline & Aile ve & $\begin{array}{l}\text { Öğretmenliğin } \\
\text { görülmemesi }\end{array}$ & 2 \\
\hline & & Öğrenci ve velilerin olumsuz tutum ve davranıșları & 2 \\
\hline
\end{tabular}




\begin{tabular}{llllll}
\hline $\begin{array}{l}\text { Kaynaklı } \\
\text { Nedenler }\end{array}$ & $\begin{array}{l}\text { Eğitimle bir şeylerin değiştirilemeyeceğine olan } \\
\text { inanç }\end{array}$ & & & 1 \\
\cline { 2 - 5 } & $\begin{array}{l}\text { Başarısızlığının } \\
\text { bağlama }\end{array}$ & nedenini & sadece & öğretmene & \\
\cline { 2 - 5 } & & & & Toplam & 6 \\
\hline
\end{tabular}

Tablo 1 incelendiğinde kendini ișe verememenin mesleki bağl1lık ve mesleki tutum ile ilgili nedenlerinin 3 tema altında kategorize edildiği görülmektedir. Bir diğer ifadeyle üç tema altındaki nedenler öğretmenlerin mesleki bağlılıklarını ve mesleki tutumlarını olumsuz etkileyerek öğretmenlerin kendilerini işe verememelerine neden olan hususlar olarak ortaya çıkmıştır.

Öğretmenlerin kendini işe verememelerinin mesleki bağl1lıkları ve mesleki tutumları ile ilgili nedenlerinden "Kişisel Nedenler" temasına bakıldığında en fazla; öğretmenlik mesleğini sevmeme, yanlış meslek seçiminde bulunma, öğretmenlik mesleğini maddi kaygılardan dolayı yapma ve üniversite puanının ancak öğretmenlik bölümünü kazanmaya yetmiş olmasından dolayı seçilmesi durumlarının, kendini işe verememenin mesleki bağlılık ve tutum ile ilgili "kişisel nedenleri”" olarak ifade edilmiştir. Bunun yanı sıra öğretmenlik mesleğini zorunluluktan dolayı yapıyor olma, bu mesleği tanımadan seçmiş olma ve öğretmenlik mesleğinin yıpratıcı olması nedenlerinin diğer kişisel nedenler olarak öne çıktığı görülmektedir.

Kendini işe verememenin mesleki bağlllık ve mesleki tutum ile ilgili nedenlerinden "Meslektaş, Okul, Üst Yönetim Kaynaklı Nedenler" temasına bakıldığında; meslektaşların motivasyon kırıcı tutum ve davranışlarının, öğretmen başarılarının ödüllendirilmeyişinin, üst makamların olumsuz tutum ve davranışlarının, yönetimin öğretmenlere değersizlik duygusu yaşatmasının ve mesleğin başındaki idealistliğin süreç içerisinde hayal kırıklığına dönüşmesinin bu tema altındaki nedenler olarak ortaya çıktığı görülmektedir.

Kendini işe verememenin mesleki bağl1lık ve mesleki tutumla ilgili nedenlerinden "Aile ve Toplum Kaynaklı Nedenler" temasına bakıldığında; en fazla, öğretmenliğin toplumda saygın bir meslek olarak görülmemesi ve öğrencilerin/velilerin olumsuz tutum ve davranışlarının mesleki bağlılı̆̆ 1 ve mesleki tutumu olumsuz etkileyen nedenler olduğu belirtilmiştir. Eğitimle bir şeylerin değiştirilemeyeceğine olan inanç ve başarısızlığın sadece öğretmene bağlanması da öne çıkan diğer nedenler olarak ortaya çıkmıştır. Öğretmenlerin açıklamalarına örnek olabilecek bazı alıntılar aşağıda sunulmuştur:

“..... Maalesef "hiçbir şey olamadın bari öğretmen ol" mantığında seçildiği için mesleğe olan sevgi ve bağlılık günden güne azalmaktadır.” (Ö1) 
"Mesleğim toplum tarafından özel ve saygıdeğer görünüyor mu? Hayır." (Ö8)

"İstediği bir alana yerleşemeyip öğretmenlik alanına yerleşmenin, öğrencinin/velinin olumsuz tutum ve davranışlarının öğretmenlik sevgisini azaltmas1." (Ö14)

“... Bizim bağlılığımız ve sevgimiz iş arkadaşlarımızın bizi eleştirmeleriyle zorlaşıyor. "Bunu neden bu kadar ince düşündün, öğrenciden bir şey olmaz" zırvalıkları bizleri yıpratıyor." (Ö16)

"Bazı öğretmenlerin yanlış meslek seçiminden dolayı işini severek yapmaması, sadece para kazanma amaçlı yapmasından dolayı kendilerini işlerine yeterince verememekteler.” (Ö21)

“... Mesleki başarılar da ödüllendirilmiyor.” (Ö24)

"Eğitim öğretimdeki başarısızlığın sadece öğretmene fatura edilmesi mesleğe olan tutumumu olumsuz etkiliyor.” (Ö30)

\section{Öğretmenlerin Kendini İşe Verememelerinin Aile ile İlgili Nedenleri}

Öğretmenlerin kendini işe verememelerinin aile ile ilgili nedenlerine ilişkin görüşlerinin analizi sonucu elde edilen tema ve bu temaya ilişkin kodlar Tablo 2'de verilmiştir.

Tablo 2. Öğretmenlerin Kendini İşe Verememelerinin Aile ile İlgili Nedenleri

\begin{tabular}{|c|c|c|}
\hline & & Frekans \\
\hline & Aile içi sorunlar, iletişimsizlikler, huzursuzluklar & 15 \\
\hline & Aile bireylerinde görülen ciddi sağlık problemleri & 6 \\
\hline & Küçük çocukların bakımı ile ilgili sorunlar & 5 \\
\hline & $\begin{array}{l}\text { Aileye ayrılan zamanın nicelik ve nitelik yönünden yetersiz } \\
\text { oluşu }\end{array}$ & 5 \\
\hline & Parçalanmış aile olma durumu & 3 \\
\hline & İşteyken çocuklarının kalabileceği uygun ortam bulamama & 3 \\
\hline & Yakınlarının sorumluluklarını da üstlenme zorunluluğu & 3 \\
\hline & Evde bakıma muhtaç birinin varlı̆ğ1 & 2 \\
\hline & Aile içi şiddet & 2 \\
\hline & Kendi çocuklarının eğitimiyle ilgili sorumlulukların varlığı & 2 \\
\hline & İşi eve taşımanın ailede doğurduğu çatışma & 2 \\
\hline & Özel hayatını işe karıştırma & 1 \\
\hline & Ailenin maddi sıkıntıları & 1 \\
\hline & Ev işlerinin fazlalığ1 & 1 \\
\hline & Eşin farklı mesleğinden dolayı çatıșma yaşanması & 1 \\
\hline
\end{tabular}


Tablo 2'de kendini işe verememenin aile ile ilgili nedenlerine bakıldığında; aile içi sorunların, iletişimsizliklerin ve huzursuzlukların yaşanması, aile bireylerinin ciddi sağlık problemleri yaşamaları, küçük çocukların bakımı konusunda yaşanan zorluklar, aileye yeterli nitelikte ve nicelikte zaman ayrılamaması, parçalanmış aile olma ve öğretmenlerin çocuklarını bırakılabilecekleri uygun ortam bulmada sıkıntı yaşamaları nedenlerinin öğretmenlerin kendini işe verememelerinin aile ile ilgili nedenlerinden en fazla vurgulanan nedenler olduğu görülmektedir. Bu nedenlerin yanı sıra evde bakıma muhtaç birinin varlığı ve aile içinde yaşanan şiddet de öne çıkan diğer nedenler olarak belirlenmiştir. Katılımcıların bu konudaki görüşlerine örnek olabilecek bazı açıklamaları aşağıdaki gibidir:

“Aile içerisindeki huzursuzluklar, tartışmaların yaşanması.” (Ö3)

“... Aradaki denge (ev-okul) sağlanmazsa öğretmen kendini işe veremeyebilir.” (Ö6)

"Bayan öğretmenlerin çocuk bakımı konusunda izinlerinin yetersizliği." (Ö7)

"İ̧s yoğunluğu nedeniyle aileme yeterli zamanı ve özeni gösteremiyorum.”(Ö12)

"Her insanda olabileceği gibi öğretmenlerin aile hayatındaki inişli çıkışlı dönemler, psikolojik açıdan öğretmeni etkileyebiliyor." (Ö18)

"Bütün enerjimi okulda harcayıp kendi çocuklarımla fazla ilgilenememem. (Ö30)

"Ailede hasta varsa, geçimsizlik varsa, çocuğu ile ilgili sorunlar varsa bunlar kendini işe verememenin nedeni olabilir." (Ö31)

\section{Öğretmenlerin Kendini İşe Verememelerinin İçinde Bulunulan Ekonomik Durum ve Mesleğin Gelir Düzeyi ile İlgili Nedenleri}

Öğretmenlerin kendini işe verememelerinin içinde bulunulan ekonomik durum ve mesleğin gelir düzeyi ile ilgili nedenlerine ilişkin katılımcı görüşlerinin analizi sonucu elde edilen tema ve bu temaya ilişkin kodlar Tablo 3 'te verilmiştir. 
Tablo 3. Öğretmenlerin Kendini İşe Verememelerinin İçinde Bulunulan Ekonomik Durum ve Mesleğin Gelir Düzeyi ile İlgili Nedenleri

\begin{tabular}{|c|c|c|}
\hline \multirow{2}{*}{\multicolumn{3}{|c|}{ jelirin ihtiyaçları karşılayamaması }} \\
\hline & & \\
\hline \multirow{2}{*}{ : } & Yaşanan ekonomik krizler ve pahalılık & 6 \\
\hline & Ek iş yapmak zorunda kalmak & 5 \\
\hline \multirow{3}{*}{ 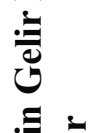 } & Kişisel gelişime harcayacak paranın olmayış1 & 3 \\
\hline & Çocuk ve eş yardımının yetersiz olması & 2 \\
\hline & Eşin çalışıyor olmaması & 1 \\
\hline \multirow{4}{*}{ 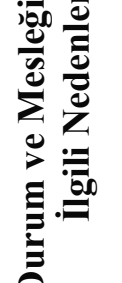 } & $\begin{array}{l}\text { Maaşların azlığından dolayı kaliteli bir yaşam } \\
\text { sürülememesi }\end{array}$ & 1 \\
\hline & Öğretmenin işini yaparken cebinden harcaması & 1 \\
\hline & $\begin{array}{l}\text { Eş ve çocukları dışında aile bireylerine bakma zorunda } \\
\text { kalmaları }\end{array}$ & 1 \\
\hline & Gelir gider dengesini sağlayamama & 1 \\
\hline \multirow{4}{*}{ 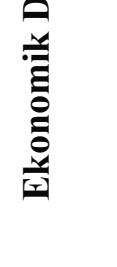 } & $\begin{array}{l}\text { Toplum nazarında ekonomik yönden saygınlığın } \\
\text { olmaması }\end{array}$ & 1 \\
\hline & Kesinti ve vergilendirmeler & 1 \\
\hline & $\begin{array}{l}\text { Ücretli olarak ya da özel okulda çalışmanın ekonomik } \\
\text { kaygı oluşturması }\end{array}$ & 1 \\
\hline & Toplam & 45 \\
\hline
\end{tabular}

Tablo 3 'te kendini işe verememenin ekonomik durum ve mesleğin gelir düzeyi ile ilgili nedenlerine bakıldığında; öğretmenlerin gelirlerinin ihtiyaçlarını karşılayamaması nedeninin bütün katılımcılar tarafından ifade edildiği görülmektedir. Bunun dışında ifade edilen diğer nedenler ise en fazla; ülkede yaşanan ekonomik krizler ve pahalılık, ek iş yapmak zorunda kalınması, kişisel gelişime harcayacak paranın olmayışı, çocuk ve eş yardımının yetersiz oluşu nedenleridir. Bu nedenlerin dışında maaşların azlığından dolayı kaliteli bir yaşam sürülememesi ve toplum nazarında ekonomik yönden saygınlığın olmaması nedenleri de kendini işe verememenin ekonomik durum ve mesleğin gelir düzeyi ile ilgili nedenleri olarak görülmektedir. Öğretmenlerin bu konudaki görüşlerine örnek olabilecek bazı ifadeleri aşağıdaki gibidir:

“...Günümüz koşullarında şunu diyebiliriz ki daha iyi şartlarda çalışıyor olmak öğretmenlerimizin verimini arttırabilir, öğretmenlik mesleğinin cazibesini arttırabilir." (Ö1)

“...Şu anda olan ekonomik pahalılık ve maaşın değerinin düşmüş olması.” (Ö2)

“... Gelirin giderleri karşılamada yetersiz kalması, eşi çalışmayan öğretmenlerin 
yaşadığı maddi zorluklar.” (Ö3)

"Öğretmenlik mesleğinin toplum nezdinde ekonomik anlamda tam tatmin edici düzeyde görülmemesi öğretmende kendini işine verememede etkili olabilir." (Ö6)

"Mesleğimizin gelir düzeyi, mutlu ve borçları düşünmeden okula gitmemize büyük bir engel. Birçok öğretmen acaba nerden özel ders verebilirim diye bakıyor. Ekonomik olarak kafası rahat olmalı öğretmenin elbette.” (Ö8)

“Gelir getirici ikinci işlerle uğraşma, geçim sıkıntısı, ekonomik krizler.” (Ö13)

"Hiçbir öğretmenin gözü ikinci bir işi aramamalı, en azından kendini ve ailesinin sosyal ihtiyaçlarını temin edebilecek düzeyde olabilmeli. Öğretmenin gözü ikinci işlere kaydığında motivasyonu düşüyor.” (Ö29)

Öğretmenlerin Kendini İșe Verememelerinin Ülkedeki Siyasal/Politik Gelişmelerle İlgili Nedenleri

Öğretmenlerin kendini işe verememelerinin ülkedeki siyasal/politik gelişmelerle ilgili nedenlerine ilişkin katılımcı görüşlerinin analizi sonucu elde edilen tema ve bu temaya ilişsin kodlar Tablo 4 'te verilmiştir.

Tablo 4.Öğretmenlerin Kendini İşe Verememelerinin Ülkedeki Siyasal/Politik Gelişmelerle İlgili Nedenleri

\begin{tabular}{|c|c|c|}
\hline \multirow{14}{*}{ 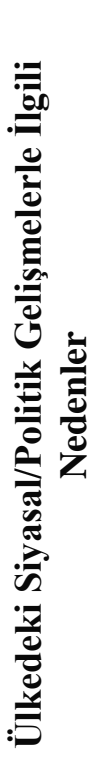 } & & Frekans \\
\hline & $\begin{array}{l}\text { Eğitim politikalarının, sisteminin, mevzuatının sik sik } \\
\text { değișmesi }\end{array}$ & 6 \\
\hline & Siyasal ve politik gelişmelerden duyulan kayg1 & 6 \\
\hline & Ülke sorunlarının yarattığı umutsuzluk & 2 \\
\hline & Öğretmen üzerindeki denetim/kamuoyu baskıs1 & 2 \\
\hline & $\begin{array}{l}\text { Öğretmen istihdam/yer değiştirme politikalarının } \\
\text { yanlıslığ } 1\end{array}$ & 2 \\
\hline & $\begin{array}{l}\text { Siyasi otoritenin öğretmenin yanında olduğunu } \\
\text { hissettirmemesi }\end{array}$ & 2 \\
\hline & Okuldaki bazı grupların ayrıcalıklı olması & 2 \\
\hline & Okul türleri arasında ödenek sağlamada ayrım yapılması & 1 \\
\hline & Gelir politikasındaki adaletsizlik & 1 \\
\hline & Terörün olduğu bölgelerde görev yapmak & 1 \\
\hline & Savaş, darbe ve krizler & 1 \\
\hline & Bimer, Cimer vb. uygulamaların olumsuz yansimas & 1 \\
\hline & Her şeyin eğitime bağlanması & 1 \\
\hline & Eğitimin konuşulduğu kadar önemli görülmemesi & 1 \\
\hline
\end{tabular}




\begin{tabular}{lc} 
Milli Eğitim bakanlarının sık sık değişmesi & 1 \\
\hline Milli Eğitim bakanının eğitimci olmaması & 1 \\
\hline Siyasi yapının eğitimle sürekli oynaması & 1 \\
\hline Siyasal kutuplaşmalar & 1 \\
\hline Torpilin olması & 1 \\
\hline Öğretmenlerin kendini güvende hissetmemeleri & 1 \\
\hline \multicolumn{1}{c}{ Toplam } & 35
\end{tabular}

Tablo 4 'te kendini işe verememenin ülkedeki siyasal/politik gelişmelerle ilgili nedenleri incelendiğinde; öğretmenlerin kendini işe verememelerinin en fazla; eğitim politikalarının, eğitim sisteminin ve mevzuatının sık sık değişmesinin, öğretmenlerin siyasal ve politik gelişmelerden kaygı duymalarının, ülke sorunlarının yarattı̆̆ umutsuzluğun, öğretmen üzerindeki denetim ve kamuoyu baskısının, öğretmen istihdam ve yer değiştirme politikalarının yanlışlı̆̆ının, siyasi otoritenin öğretmenin yanında olduğunu hissettirmemesinin ve bazı gruplara ayrıcalıklı davranılmasının öğretmenlerin kendilerini işe verememelerinin nedenleri olduğu belirlenmiştir. $\mathrm{Bu}$ nedenlerin dişında öğretmenlerin terör bölgelerinde görev yapıyor olmaları ve Bimer-Cimer uygulamalarının olumsuz yansımaları nedenleri de öne çıkan diğer nedenler olarak görülmektedir. Öğretmenlerin bu konudaki görüşlerine örnek olabilecek bazı ifadeleri aşağıdaki gibidir:

"Milli Eğitim Bakanlarının çok sık değişmesi, ..., siyasi yapının eğitime çok müdahale etmesi.” (Ö3)

"Bimer, Cimer politikalarının öğretmenin kendini işine verememesinde etkili olması, ..., velilere, öğretmene müdahale ortamının çok sunulmuş olması.” (M6).

"Sürekli değişen bir sistem var. Her gelen bakan ya da siyasi görüşe göre değişen sistem ne kadar başarılı oluyorsa öğretmen de o kadar mutlu işini yapıyor." (Ö8)

"Bazı makam ve mevkilerin sadece siyasi olarak aynı görüşe sahip kişilere verildiğini düşünüyorum.” (Ö28)

\section{Öğretmenlerin Kendini İşe Verememelerinin Görev Yapılan Yerin Sosyokültürel ve Sosyoekonomik Özellikleri ile İlgili Nedenleri}

Öğretmenlerin kendini işe verememelerinin görev yapılan yerin sosyokültürel ve sosyoekonomik özellikleri ile ilgili nedenlerine ilişkin katılımcı görüşleri üzerinde yapılan analizi sonucu ulaşılan tema ve kodlar Tablo 5'de verilmiştir. 
Tablo 5.Öğretmenlerin Kendini İşe Verememelerinin Görev Yapılan Yerin Sosyoekonomik ve Sosyokültürel Özellikleri ile İlgili Nedenleri

\begin{tabular}{|c|c|c|}
\hline \multicolumn{3}{|c|}{ C". } \\
\hline \multirow{2}{*}{ ".00 } & Görev yapılan yerin düșük sosyoekonomik durumu & 10 \\
\hline & $\begin{array}{l}\text { Öğretmenliğin toplum içerisindeki saygınlık ve öneminin } \\
\text { azalması }\end{array}$ & 9 \\
\hline \multirow{2}{*}{ 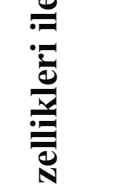 } & $\begin{array}{l}\text { Öğretmene/eğitime olumsuz bakış ve önyarg1 (değer } \\
\text { verilmemesi) }\end{array}$ & 8 \\
\hline & $\begin{array}{l}\text { Sosyal ve kültürel etkinlikleri yapacak imkanların } \\
\text { yetersizliği }\end{array}$ & 5 \\
\hline \multirow{5}{*}{ 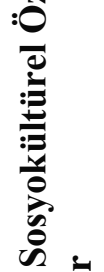 } & Halkın yeniliğe kapalı ve bilinçsiz oluşu & 3 \\
\hline & Görev yapılan yerdeki halkın farklı inanç ve ideolojileri & 3 \\
\hline & Gelişmemiş çevre koşulları & 3 \\
\hline & Görev yerine uyumda problem yaşama & 3 \\
\hline & Coğrafi bölgeler arasındaki sosyoekonomik farklılıklar & 3 \\
\hline \multirow{2}{*}{ 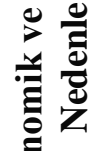 } & $\begin{array}{l}\text { Bireylerin eğitimin önemini ve gereğini anlayamamış } \\
\text { olmaları }\end{array}$ & 3 \\
\hline & Velilerin, velisi oldukları öğrencilerle ilgilenmemeleri & 2 \\
\hline & Eğitim düzeyi düşük yerlerde öğretmene uygulanan şiddet & 2 \\
\hline & Velilerce eğitime gerekli harcamaların yapılmaması & 2 \\
\hline & Aile yapısı ile eğitimin çatışması & 1 \\
\hline & Mesleki gelişim imkanlarının olmayışı & 1 \\
\hline \multirow{5}{*}{ 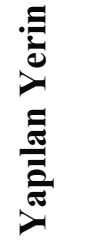 } & Ulaşım problemleri & 1 \\
\hline & Ahlaki problemlere daha çok vakit harcama & 1 \\
\hline & Araç gereç materyal eksikliği & 1 \\
\hline & Öğretmen ile bölge halkı arasındaki kültürel farklılıklar & 1 \\
\hline & Toplumun eğitim seviyesi & 1 \\
\hline \multirow{4}{*}{ ن } & Bireylerin sabit fikirlilikleri & 1 \\
\hline & Değerlerde görülen hızlı yozlaşma & 1 \\
\hline & Her şeyin ögretmenden beklenmesi & 1 \\
\hline & Toplam & 66 \\
\hline
\end{tabular}

Tablo 5'e göre kendini işe verememenin görev yapılan yerin sosyokültürel ve sosyoekonomik özellikleri ilgili nedenlerinden en fazla; görev yapılan yerin düşük sosyoekonomik durumu, öğretmenliğin toplum içindeki saygınlığının ve öneminin azalmış olması, öğretmene ve eğitime toplumun olumsuz ve ön yargılı bakış1, sosyal ve kültürel etkinlikleri yapacak imkanların yetersiz oluşu, halkın yeniliğe kapalı ve bilinçsiz oluşu, görev yapılan yerdeki halkın eğitime bakışının olumsuz oluşu, halkın farklı inanç ve ideolojilere sahip olması, gelişmemiş çevre koşulları, görev yerine uyumda problemlerin yaşanması, coğrafi bölgeler 
arasındaki farklılıklar ile bireylerin eğitimin önemini ve gereğini anlayamamış olmaları nedenlerinin sıralandığı görülmektedir. Görev yapılan yerle ilgili olarak öğretmenlerin mesleki gelişim imkânlarının olmaması, öğretmenlerin yaşadıkları ulaşım problemleri, her şeyin öğretmenden beklenmesi, öğretmenlerin ve bölge halkının kültürel farklılıkları da kendini işe verememenin bir diğer nedeni olarak belirlenmiştir. Öğretmenlerin bu konudaki görüşlerine örnek olabilecek bazı ifadeleri aşağıdaki gibidir:

"Sosyokültürel olarak geri kalmış bölgelerde eğitime gereken önemin verilmeyişi, gelir düzeyi düşük olan bölgelerde eğitim için gerekli yeterli harcamanın yapılmaması, çocukların bir an önce hayata atılmasını isteyen verililerin eğitim faaliyetlerini gereksiz bulması." (Ö4)

"Öğretmenlik mesleğinin toplumdaki yeri. ... "Hiç olmazsa öğretmen ol" derken bile öğretmenlik mesleğinin diğer mesleklerin (tıp, mühendislik vb...) gerisinde görülmesi.” (Ö5)

“Öğretmene gereken değerin verilmemesi, eğitimin öneminin yeterince anlaşılamamış olması, toplumun eğitimin gereğine olan inancının zayıf olması, toplumun eğitim seviyesi." (Ö14)

"Üst seviyede bir sosyoekonomik ve sosyokültürel yapı ile birleşen bilinçsiz veli, öğretmeni maddi ve manevi olarak ezmektedir. Alt seviyedeki mahalle ve köylerde ise öğretmenler, velileri tarafından terk edilen öğrenciler ile eğitim ögretim sürecini tek başına üstlenme sorumluluğundan dolayı meslekten uzaklaşmaktalar." (Ö15)

“... Öğretmene yapılan saygısızlıklar, malzeme yetersizliği vs.” (Ö21)

\section{Öğretmenlerin Kendini İșe Verememelerinin Toplumun Eğitime/Öğretmene Bakışı ile İlgili Nedenleri}

Öğretmenlerin kendini işe verememelerinin toplumun eğitime/öğretmene bakışı ile ilgili nedenlerine ilişkin katılımcı görüşlerinin analizi sonucu elde edilen tema ve bu temaya ilişkin kodlar Tablo 6'da verilmiştir. 
Tablo 6.Öğretmenlerin Kendini İşe Verememelerinin Toplumun Eğitime/Öğretmene Bakışı ile İlgili Nedenleri

\begin{tabular}{|c|c|c|}
\hline \multirow{15}{*}{ 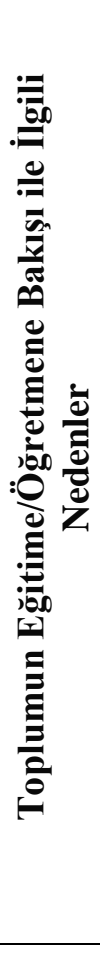 } & & Freke \\
\hline & $\begin{array}{l}\text { Eğitimin ve öğretmenin toplumdaki saygınlığının azalmış } \\
\text { olması }\end{array}$ & 31 \\
\hline & Öğretmenleri küçük düşürücü söz, tavır ve hareketler & 3 \\
\hline & Velilerin öğretmenlere karșı yargılayıc1 tutumları & 2 \\
\hline & $\begin{array}{l}\text { Toplumun okula bakımevi, öğretmene bakıcı gözüyle } \\
\text { bakması }\end{array}$ & 2 \\
\hline & $\begin{array}{l}\text { Veli ve öğrencilerin görevlerini yapmadan, her şeyi } \\
\text { öğretmenden beklemeleri }\end{array}$ & 2 \\
\hline & $\begin{array}{l}\text { Öğretmenliğin, az çalış1lıp çok tatil yapılan bir meslek } \\
\text { olarak görülmesi }\end{array}$ & 2 \\
\hline & Toplumun, eğitimden çok sınav skorlarını önemsemesi & 1 \\
\hline & Olumsuz örneklerin tüm öğretmenlere mal edilmesi & 1 \\
\hline & Toplumun, öğretmenliği basite alınması & 1 \\
\hline & $\begin{array}{l}\text { Toplumun, öğretmenliği çok rahat bir meslek olarak } \\
\text { görmesi }\end{array}$ & 1 \\
\hline & $\begin{array}{l}\text { Toplumun, öğretmenliği çok para kazanan bir meslek olarak } \\
\text { görmesi }\end{array}$ & 1 \\
\hline & Öğretmenden olağanü: & 1 \\
\hline & Herkesin öğretmenin ișine müdahale etmesi & 1 \\
\hline & Toplam & 49 \\
\hline
\end{tabular}

Tablo 6'da kendini işe verememenin toplumun eğitime/öğretmene bakışı ile ilgili nedenlerine bakıldığında; eğitimin ve öğretmenin toplumdaki saygınlığının azalmış olması, öğretmenleri küçük düşürücü söz, tavır ve hareketlerin varlığı, velilerin öğretmenlere karşı yargılayıcı tutumları, toplumun okula bakımevi öğretmene ise bakıc1 gözüyle bakması, velilerin/öğrencilerin görevlerini yapmadan her şeyi ögrretmenden beklemeleri, toplumun öğretmenliği az çalışlıp çok tatil yapılan bir meslek olarak görmesi şeklinde nedenlerin ortaya çıktığı görülmektedir. Bu nedenlerin yanı sıra toplumun eğitimden çok sınav skorlarını önemsemesi, toplumun öğretmenliği basite alması nedenlerinin de dikkat çeken diğer nedenler olduğu görülmektedir.

Öğretmenlerin bu konudaki görüşlerine örnek olabilecek bazı beyanları aşağıdaki gibidir:

“... Öğretmenlerin az çalıştıklarını düşünen, tatilini fazla bulan rahatsız edici söylemlerle de karşılaşılmakta.” (Ö1) 
"Öğretmenliğin çok rahat bir meslek olarak görülmesi, öğretmenin çok para kazandığının ve çok tatil yaptığının zannedilmesi." (Ö3)

"Velilerin öğretmene karşı yargılayıcı tutumları, günlük hayatta ortaya çıkan bazı olumsuz davranışların toplum tarafından tüm öğretmenlere mal edilmesi." (Ö5)

"Sınavdan iyi alan öğrenci iyi öğrenci. Diğer edep, ahlak eğitimi önemli değildir. Testte doğruyu işaretleten öğretmen iyidir.” (Ö15)

"Toplumun, öğretmenin yaptığ 1 işe fazlasıyla müdahale etmesinden dolay öğretmenlerin kendini işe vermesini olumsuz etkilemiştir." (Ö21)

"Eğitim değersizleşti, öğretmenin otoritesi sarsıld1." (Ö30)

"Toplumumuz maalesef öğretmenin elinde sihirli değnek var sanıyor. Kendi ilgisi, çocuğun çalışması olmadan bir yere gelinmeyeceğini anlamayıp, öğretmenden çok şey bekliyorlar." (Ö31)

"Eskiden önünde düğme iliklenen bir meslekken, şu an dayak yiyen, hor görülen bir meslektir.” (Ö32)

Öğretmenlerin Kendini İşe Verememelerinin Sosyal Medya ve Diğer İletişim Araçlarındaki Yayınlar ile İlgili Nedenleri

Öğretmenlerin kendini işe verememelerinin sosyal medya ve diğer iletişim araçlarındaki yayınlarla ilgili nedenlerine ilişkin katılımcı görüşlerinin analizi sonucu elde edilen tema ve bu temaya ilişkin kodlar Tablo 7'de verilmiştir.

Tablo 7. Öğretmenlerin Kendini İșe Verememelerinin Sosyal Medya ve Diğer İletişim Araçlarındaki Yayınlar ile İlgili Nedenleri

\begin{tabular}{|c|c|c|}
\hline \multirow{8}{*}{ 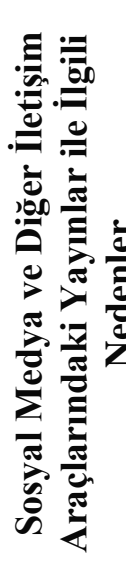 } & & Frekans \\
\hline & $\begin{array}{l}\text { Öğretmenlerle ilgili aşağılayıcı ve itibarsılaştırıcı } \\
\text { yayınların yapılması }\end{array}$ & 12 \\
\hline & Medyada çoğunlukla olumsuz olayların sunulması & 8 \\
\hline & $\begin{array}{llll}\text { Medyadaki olumsuz haberlerin toplumda önyarg1 } \\
\text { olusturmas1 }\end{array}$ & 2 \\
\hline & Yayınlarla öğretmenliğe karşı olumsuz alg1 oluşturulması & 2 \\
\hline & $\begin{array}{l}\text { Medyada öğretmenliğin şiddet eğilimli bir meslek olarak } \\
\text { lanse edilmesi }\end{array}$ & 2 \\
\hline & Öğretmenlerin cinsel tacizle anılması & 1 \\
\hline & $\begin{array}{l}\text { Yetkililerin, topluma öğretmenlerle ilgili olumsuz mesaj } \\
\text { vermesi }\end{array}$ & 1 \\
\hline
\end{tabular}




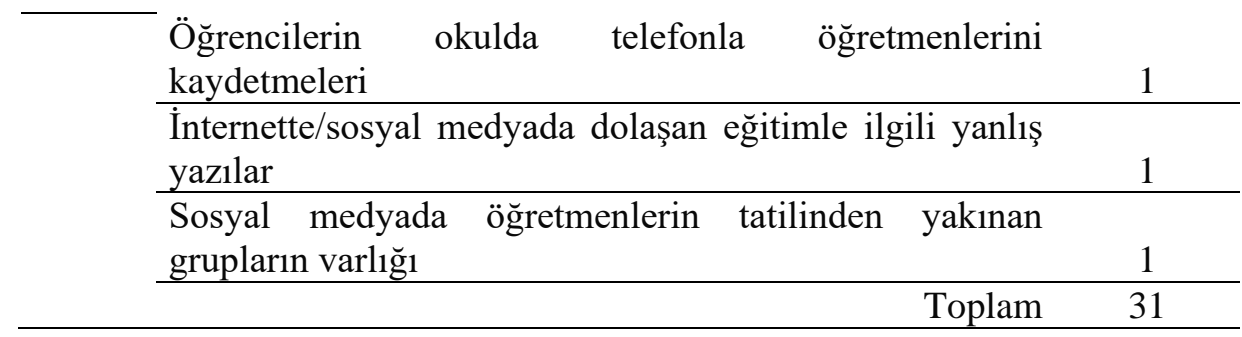

Tablo 7'de kendini işe verememenin sosyal medya ve diğer iletişim araçlarındaki yayınlar ile ilgili nedenlerine bakıldığında en fazla olarak; öğretmenlerle ilgili aşağılayıcı ve itibarsızlaştırıcı yayınların yapılması, medyada öğretmenlerle ilgili çoğunlukla olumsuz olayların sunulması, medyadaki olumsuz haberlerin toplumda önyarg1 ve olumsuz alg1 oluşturması ve medyada öğretmenliğin şiddet eğilimli bir meslek olarak lanse edilmesi nedenlerinin ifade edildiği görülmektedir. $\mathrm{Bu}$ nedenlerin dışında öğretmenlerin cinsel tacizle anılması, yetkililerin topluma öğretmenlerle ilgili olumsuz mesaj vermeleri, internette ve sosyal medyada dolaşan eğitimle ilgili yanlış yazılar nedenlerinin de öne çıkan diğer nedenler olduğu belirlenmiştir.

Öğretmenlerin bu konudaki görüşlerine örnek olabilecek bazı beyanları aşağıdaki gibidir:

"Sosyal medyada tatilden ve az çalışmamızdan bahseden bir güruh var.” (Ö1)

"Çok kısa sürede yayılan yalan yanlış haberler ve öğretmenin çalışmaması ve 3 ay tatil gibi toplumda oluşturulan algılarla öğretmenin küçük, değersiz gösterilmesi.” (Ö2)

"Okullarda meydana gelen bazı olumsuz davranışların sosyal medya aracılığıyla servis edilmesi ve bunun sonucunda okul ve ögretmenin hedef alınması, internette ve diğer sosyal medya alanlarında eğitimle ilgili bilimsel dayanağı olmayan yazıların paylaşılması." (Ö5)

"Vaktiyle ........'in bir çocuk mu önemli otuz çocuk mu önemlidir diye, öğretmenin aile düzenini, değerini hiçe sayan bir bakanın bakış açısı, topluma sonu düşünülmeden verilen eleştiri yetkileri, öğretmene şiddet vs." (Ö7)

“Öğretmenlerin sosyal medyada dayak şiddet haberleriyle duyurulması mesleği itibarsılaştırıyor." (Ö19)

"Öğretmenin en ufak bir hatası bile manşetlerde yer alırken öğretmene yapılan haksızlıklar görmezden geliniyor." (Ö30) 
Öğretmenlerin Kendini İşe Verememelerinin Okul Paydaşları ile İlgili Nedenleri

Öğretmenlerin kendini işe verememelerinin okul paydaşlarıyla ilgili nedenlerine yönelik bulgular MEB-İlçe/İl Milli Eğitim Müdürlükleriyle İlgili Nedenler, Okul İdarecileriyle İlgili Nedenler, Kurumdaki Öğretmenlerle İlgili Nedenler, Öğrencilerle İlgili nedenler, Velilerle İlgili Nedenler ve Diğer Personellerle İlgili Nedenler başlıkları altında ayrı ayrı ele alınarak sunulmuştur.

Öğretmenlerin Kendini İșe Verememelerinin Okul Paydaşları (Bakanlık “MEB” ve İlçe/İl Milli Eğitim Müdürlükleri) ile İlgili Nedenleri

Öğretmenlerin kendini işe verememelerinin bakanlık ve ilçe/il milli eğitim müdürlükleri ile ilgili nedenlerine ilişkin katılımcı görüşlerinin analizi sonucu elde edilen tema ve bu temaya ilişkin kodlar Tablo 8'de verilmiştir.

Tablo 8. Öğretmenlerin Kendini İşe Verememelerinin MEB ve İlçe/İl Milli Eğitim Müdürlükleri ile İlgili Nedenler

\begin{tabular}{|c|c|c|}
\hline \multirow{3}{*}{ : } & Üst kademe vöneticilerin öğretmene değer vermemeleri & $\begin{array}{c}\text { Frekans } \\
4\end{array}$ \\
\hline & $\begin{array}{l}\text { Üst kademe yöneticilerin öğretmeni korumamaları, } \\
\text { valnız bırakmaları }\end{array}$ & 4 \\
\hline & Öğretmene çok fazla sorumluluk yüklemeleri & 4 \\
\hline \multirow{5}{*}{ 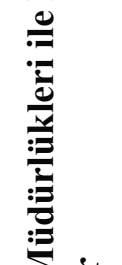 } & Evrak işlerindeki yoğunluk ve gecikmeler & 4 \\
\hline & Başarısızlıklarda faturanın öğretmene kesilmesi & 2 \\
\hline & Ödüllendirmenin olmayıș1 & 2 \\
\hline & Yöneticilerin iletişim yetersizlikleri & 2 \\
\hline & Öğretmenlere görev tanımı dışındaki işlerin yaptırılması & 2 \\
\hline \multirow{4}{*}{ 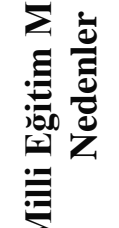 } & $\begin{array}{l}\text { Yöneticilerin gerekli olan fiziki alt yapı ve donanımı } \\
\text { sağlayamamaları }\end{array}$ & 2 \\
\hline & Terfi ve atamalardaki haksızlıklar & 1 \\
\hline & Kadrolaşmanın olması & 1 \\
\hline & Alınan kararların sadece merkeze göre alınması & 1 \\
\hline \multirow{7}{*}{ 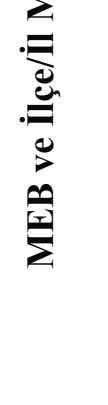 } & $\begin{array}{l}\text { Sonucu iyi işlerde, yönetimin sadece kendini ön plana } \\
\text { çıarması }\end{array}$ & 1 \\
\hline & Bakanlığın sık s1k uygulama değiştirmesi & 1 \\
\hline & $\begin{array}{l}\text { Yöneticilerin uygulamadan habersiz olarak okulları } \\
\text { yönetmeleri }\end{array}$ & 1 \\
\hline & Alınan kararların kâğıt üzerinde kalması & 1 \\
\hline & Alınan kararlara öğretmen katılımının sağlanmaması & 1 \\
\hline & Öğretmen nakillerindeki zorluk & 1 \\
\hline & Toplam & 35 \\
\hline
\end{tabular}


Tablo 8'de kendini işe verememenin MEB ve ilçe/il milli eğitim müdürlükleri kaynaklı nedenlerine bakıldığında en çok ifade edilen nedenlerin; üst kademe yöneticilerin öğretmene değer vermemeleri ve öğretmeni korumayıp yalnız bırakmaları, öğretmene çok fazla sorumluluk yüklenmesi, evrak işlerinde yaşanan yoğunluk ve gecikmeler, başarısızlıklarda faturanın öğretmene kesilmesi, ödüllendirmenin olmayışı, yöneticilerin iletişim yetersizlikleri ve öğretmenlere görev tanımlarının dışındaki işlerin yaptırılması nedenleri olduğu görülmektedir. Alınan kararlarda öğretmen katılımının sağlanamaması, öğretmen nakillerindeki zorluk nedenlerinin de dikkat çeken diğer nedenler olduğu belirlenmiştir. Öğretmenlerin bu konudaki ifadelerine örnek olabilecek bazı beyanları aşağıda verilmiştir:

"Bakanlık ..., sistem değişikliklerinde yaptım oldu mantı̆̆ından ziyade paydaşlarının fikirlerine önem vermeli, sahaya inebilmelidir. Yine ilçe/il milli eğitim müdürlükleri de yapılacak iş ve işlemlerde öğretmenin yanında olmalı, iş birliğini sağlamalıdır." (Ö1)

"Müdürlüklerin herhangi bir sorun yaşandığında öğretmeni korumamaları. Öncelikle dinleyip olayı yerinde görmemeleri. Koltuktan en ücra köşedeki okul ve öğretmeni yönetmeye çalışmaları.”. (Ö2)

"Başarısızlıkların faturasının öğretmene çıkarılması.” (Ö3)

"Daha dün (gerçek anlamda dün) sınıfıma kendisini tanıtmadan girip sağa sola bakan yanında müdür yardımcısı ile beraber selamsız, iletişimsiz giren şube müdürü ve bunun gibi yöneticiler.” (Ö7)

"Yaptığımız güzel işleri ne kadar görmekteler ne kadar takdir etmekteler, yeniliklere, farklı düşünen öğretmene nasıl bakıyorlar? Sadece kendilerini ön plana çıkaracak bir fotoğraf karesi kadar bu soruların cevabı." (Ö8)

"Üst kurumların, okulların ihtiyaçlarını yeterince karşılayamamaları, kurum müdürlerinin öğretmene gerekli saygıyı göstermemeleri.” (Ö21)

\section{Öğretmenlerin Kendini İșe Verememelerinin Okul Paydaşları (Okul İdarecileri) ile İlgili Nedenleri}

Öğretmenlerin kendini işe verememelerinin okul idarecileri ile ilgili nedenlerine ilişsin katılımcı görüşlerinin analizi sonucu elde edilen tema ve bu temaya ilişkin kodlar Tablo 9'da verilmiştir. 
Tablo 9. Öğretmenlerin Kendini İşe Verememelerinin Okul İdarecileri ile İlgili Nedenleri

\begin{tabular}{|c|c|c|}
\hline \multirow{14}{*}{ 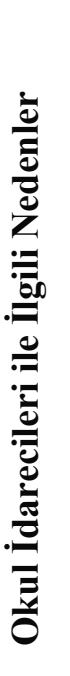 } & & Frekans \\
\hline & Okul idarecilerinin adaletsiz tutum ve davranışları & 7 \\
\hline & Okul idarecilerinin baskıcı tutumları & 6 \\
\hline & Öğretmeni takdir etmemeleri & 5 \\
\hline & İletişim becerilerinin yetersizliği & 5 \\
\hline & Öğretmeni desteklememeleri, iș birliği kurmamaları & 4 \\
\hline & Yanlı davranmaları & 4 \\
\hline & İdareciliklerinde yasal gücün ağır basması & 3 \\
\hline & Yeniliğe ve gelişmeye kapalı olmaları & 3 \\
\hline & Çözüm odaklı olmamaları & 3 \\
\hline & Egolariyla hareket etmeleri & 3 \\
\hline & Görevlendirilmelerinin adaletsiz oluşu & 2 \\
\hline & $\begin{array}{l}\text { Aidiyet duygularının olmayışı, çalışanlarında bu duyguyu } \\
\text { oluşturamamaları }\end{array}$ & 2 \\
\hline & Yöneticilik becerilerinin yetersizliği/yokluğu & 1 \\
\hline & Toplam & 48 \\
\hline
\end{tabular}

Tablo 9'da kendini işe verememenin okul idarecileriyle ilgili nedenlerinden en çok belirtilenlerin; okul idarecilerinin adaletsiz tutum ve davranışlarının ve baskıcı tutumlarının olması, öğretmeni takdir etmemeleri, iletişim becerilerinin yetersiz oluşu en fazla ifade edilen nedenler olarak ortaya çıkmıştır. $\mathrm{Bu}$ nedenlerin yanı sıra okul yöneticilerinin öğretmenlerini desteklememeleri, öğretmenleriyle iş birliği kurmamaları, öğretmenler arasında yanlı davranışlar sergilemeleri, idareciliklerinde yasal gücün ağır basması, yeniliğe ve gelişmeye kapalı olmaları, çözüm odaklı olmamaları ve egolarıyla hareket etmeleri şeklinde nedenlerin de öğretmenlerin kendilerini işe vermelerine engel olan yönetici kaynaklı nedenler olduğu belirlenmiştir.

Okul idarecilerinin aidiyet duygularının olmayışı ve çalışanlarında aidiyet duygusu oluşturamamaları, yöneticilik becerilerinin yetersizliği/yokluğu nedenleri de okul yönetimi açısından önemli olan ve öğretmenlerin kendini işe vermelerini engelleyen diğer nedenler olduğu görülmektedir.

Öğretmenlerin bu konudaki ifadelerine örnek olabilecek bazı beyanları aşağıdaki gibidir:

"Okul idarecilerinin öğretmenlikten geldiğini unutmuş gibi hareket etmeleri, ögrretmenlere re' sen görevlendirmeler yapmaları, kurum içerisinde çalışanları 
ödüllendirmeyip çalışmayanları taltif etmeleri, öğretmenlerin problemlerine çözüm bulamamaları." (Ö4)

“... Özeleştiri yapamayan, egolu idarecilerin öğretmene gelince alabildiğince eleştirme yetkisine sahip gibi davranmaları.” (Ö7)

"Mobbing uygulayan idarecilerle çalışma, çifte standart uygulamaları, yetkiyi sürekli olarak ön plana çıkaran kifayetsiz idareciler." (Ö13)

"Mesleğini en iyi şekilde yapmaya çalışan ile işini gelişigüzel yapanın aynı görülmesi, yapanın takdir edilmesinde, yapmayanın eleştirilmesinde çekimser davranılmas1." (Ö17)

"Okul idaresinin, bazen öğretmene görev verdiklerinde ve öğretmenin bu görevde başarı elde etmesi durumunda olumlu dönüt vermemeleri.” (Ö22)

"İdarenin hoşgörüsüz, sert ve aşırı disiplinli davrandığı zaman öğretmenin motivasyonunun düşeceğini düşünüyorum.” (Ö29)

\section{Öğretmenlerin Kendini İşe Verememelerinin Okul Paydaşları (Kurumdaki Öğretmenlerle) ile İlgili Nedenleri}

Öğretmenlerin kendini işe verememelerinin kurumdaki öğretmenlerle ile ilgili nedenlerine ilişkin katılımcı görüşlerinin analizi sonucu elde edilen tema ve bu temaya ilişkin kodlar Tablo 10'da verilmiştir.

Tablo 10. Öğretmenlerin Kendini İşe Verememelerinin Kurumdaki

Öğretmenler ile İlgili Nedenleri

\begin{tabular}{|c|c|c|}
\hline \multirow{12}{*}{ 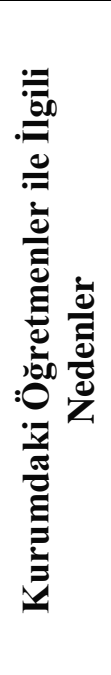 } & & Frekans \\
\hline & İletişimsizlik ya da samimi olmayan iletişim & 5 \\
\hline & İsteksiz meslektaşların varlığ 1 & 5 \\
\hline & $\begin{array}{l}\text { Üretken ve çalışkanların istekliliğinin kırılması, } \\
\text { küçümsenmeleri }\end{array}$ & 4 \\
\hline & Amaçlar için ortak hareket etmeme & 4 \\
\hline & Dedikodu & 4 \\
\hline & Çatışma ve çekişmeler & 3 \\
\hline & Gruplaşmalar & 3 \\
\hline & $\begin{array}{l}\text { Sorumluluktan kaçma, sorumluluğu başkasına yıkmaya } \\
\text { çalışma }\end{array}$ & 2 \\
\hline & İşini yapmayan meslektaşların varlığ & 2 \\
\hline & Kıskançlık & 2 \\
\hline & $\begin{array}{l}\text { Eğitim kaygısı taşımayan duyarsız meslektaşlarla birlikte } \\
\text { çalışma }\end{array}$ & 1 \\
\hline
\end{tabular}




\begin{tabular}{lll}
\hline İtici gördüğü meslektaşlarla aynı ortamı paylaşma & \\
zorunluluğu & & \\
\hline $\begin{array}{l}\text { Üst yönetimin desteğini almış öğretmenlerin } \\
\text { umursamazlığı }\end{array}$ & 1 \\
\hline Meslektaşların aidiyet hissi yaşamamaları & 1 \\
\hline Bir diğerinin iyi olmasını istememe & 1 \\
\hline Uyumsuz meslektaş varlığı & 1 \\
\hline Saygısız meslektaş varlığ & 1 \\
\hline Tutarsız meslektaş varlığı & 1 \\
\hline Isşirliğinin yokluğu & 1 \\
\hline Empati yoksunluğu & 1 \\
\hline Güvensizlik & 1 \\
\hline Rekabet & Toplam & 1 \\
\hline
\end{tabular}

Tablo 10'da öğretmenlerin kendini işe verememelerinin kurumdaki diğer öğretmenlerle ilgili nedenleri incelendiğinde en çok ifade edilen nedenlerin; öğretmenler arasında yaşanan iletişimsizlik ya da samimi olmayan iletişimin varlığı, isteksiz meslektaşların varlığı, işini iyi yapmak isteyen, üretken ve çalışkan öğretmenlerin istekliliklerinin diğer öğretmenler tarafından kırılarak küçümsenmeleri, amaçlar için ortak hareket etmeme, öğretmenler arasında yaşanan dedikodu, gruplaşmalar, kimi öğretmenlerin sorumluluktan kaçarak sorumluluğu başkasına yıkmaya çalışmaları, işini yapmayan meslektaşların varlı̆̆ 1 ve k1skançlıklar şeklinde nedenler olduğu görülmektedir.

Eğitim kaygısı taşımayan duyarsız meslektaşlarla çalışmak, üst yönetimin desteğini almış öğretmenlerin umursamazlıkları, meslektaşlarının aidiyet hissi yaşamamaları, empati ve iş birliği yoksunluğu, güvensizlik durumu ve rekabet ortamının varlığı, kurumdaki uyumsuz, saygısız ve tutarsız meslektaşlarla birlikte çalışma zorunluluğu nedenleri de bu nedenlerin dışındaki nedenler olarak öne çıkmaktadır. Öğretmenlerin bu konudaki ifadelerine örnek olabilecek bazı beyanları aşağıdaki gibidir:

"Hevessiz öğretmen, sadece iş olarak gören öğretmenlerle çalışmak. İlginç fikir ve çalışmalara duyarsız olarak tepki verip gereksiz görmeleri.” (Ö2)

"Çekişmelerin olması, kıskançlık, ortak bir paydada buluşulamaması, öğretmenin halinden anlamaması, gruplaşmaların olması." (Ö3)

“Güvensizlik, rekabet, samimiyetsiz ilişkiler.” (Ö7) 
"Sen yapmak istersin. O istemez, sana da kızar. Çünkü senin çalışman, onun çalışmadığını ortaya çıkarır. -Gel git işte derler. Yani motivasyonu etkiler." (Ö8)

“Öğretmenler arasında iş birliğinin zayıf olması.”(Ö12)

"Sevimsiz, pesimist ve eğitim gibi bir derdi olmayan öğretmenlerle bir arada çalışmak.” (Ö13)

“... Bir öğretmenin çok çalışırken diğerlerinin daha az çalışması....” (Ö21)

“... Eğer öğretmenler arasında anlaşmazlıklar, gruplaşmalar varsa bu durum da öğretmeni olumsuz etkilemektedir.” (Ö26)

"Okulda öğretmenler arası diyaloglar da verimi düşürebilir. Tartışmalar, dedikodular, verimi düşürür.” (Ö31)

\section{Öğretmenlerin Kendini İșe Verememelerinin Okul Paydaşları (Öğrencilerle) ile İlgili Nedenleri}

Öğretmenlerin kendini işe verememelerinin öğrenciler ile ilgili nedenlerine ilişkin katılımcı görüşlerinin analizi sonucu elde edilen tema ve bu temaya ilişkin kodlar Tablo 11'de verilmiştir.

Tablo 11. Öğretmenlerin Kendini İşe Verememelerinin Öğrenciler ile İlgili Nedenleri

\begin{tabular}{|c|c|c|}
\hline \multirow{11}{*}{ 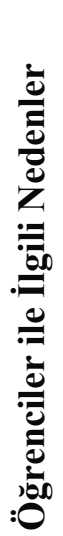 } & & Frekans \\
\hline & Öğrencilerde motivasyon, ilgi ve istek eksikliği & 14 \\
\hline & Saygısız davranıslar & 12 \\
\hline & Sorumsuzluk & 4 \\
\hline & Amaçsızlık & 2 \\
\hline & Öğrencilerin aileleri tarafından desteklenmemeleri & 1 \\
\hline & Cocukların narin ve șımarık yetiștirilmiș olmaları & 1 \\
\hline & Ahlak dışı davranışlar & 1 \\
\hline & Ailenin çocuğunu iyi yetiştirmemiş olması & 1 \\
\hline & Özel eğitim öğrencilerinin varlığı & 1 \\
\hline & $\begin{array}{l}\text { Yabancı uyruklu öğrencilerin kültürel uyum problemleri } \\
\text { yașamaları }\end{array}$ & 1 \\
\hline & Toplam & 38 \\
\hline
\end{tabular}

Tablo 11'de öğretmenlerin kendini işe verememelerinin öğrencilerle ilgili nedenlerinden en çok ifade edilenlerin; öğrencilerde motivasyon, ilgi ve istek eksikliğinin olması, öğrencilerin saygısızlık içeren davranışlarda bulunmaları, 
öğrencilerin sorumsuzluk sergilemeleri ve amaçsız olmaları şeklinde olduğu görülmektedir.

Öğrencilerin ailelerince desteklenmeyişleri, çocukların narin ve şımarık yetiştirilmiş olmaları, ahlak dışı davranışlar sergilemeleri, sınıfta özel eğitim öğrencilerinin varlığ 1 ve yabanc1 uyruklu öğrencilerin uyum problemleri de öğretmenlerin kendini işe verememelerinin öğrencilerle ilgili nedenleri olarak ortaya çıkmıştır.

Öğretmenlerin bu konudaki ifadelerine örnek olabilecek bazı beyanları aşağıdaki gibidir:

"Ödevlerini yapmamaları, ders çalışmamaları, verilen emekleri boşa çıkarmaları, saygısızlık, hakaret, şikâyet." (Ö3)

"Çocukların aşırı nazlı ve şımarık olmaları, evin müdürü, valisi, bakanı, başkanı gibi yetiştirilmeleri, en küçük bir sıkıntıya, zorluğa dayanamamaları." (Ö4)

"Özel eğitim öğrencilerinin varlığ 1 , bununla birlikte öğretmenin bu alandaki yalnızlığı öğretmenin kendini işe verememesine neden olmaktadır." (Ö6)

"Sürekli sorun çıkaran, temizlik alışkanlıklarından yoksun öğrencilerle uğraşmak. Farklı uyruklu öğrencilerle yaşanan dil ve kültür problemleri.” (Ö13)

"Motivasyonu zayıf öğrencilerin okula ve öğretmene gösterdikleri olumsuz tutumlar.” (Ö14)

"Öğrencilerin okula karşı sevgi duymaması, gelecek ile ilgili hedeflerinin olmaması." (Ö19)

"Öğrenciler anlatılanları almamakta 1srar ediyorlar. Hiçbir çaba harcamadan her şeyi öğrenelim diyorlar o da olmayınca ben olumsuz etkileniyorum. Bazen okula bile gelmek istemediğim oluyor." (Ö23)

“Öğrencilerin saygısız olması, derse ilgisiz olması verimi düşürür.” (Ö31)

“Öğrenmeye istekli öğrenciler gerekmektedir. Öğretmeni zorlayan öğrenciler olmalıdır. Öğrenci isteksiz olursa otomatik olarak öğretmen de isteksiz oluyor. Bilgiye aç bir sınıf, öğretmeni çalışmaya iter.” (Ö33) 


\section{Öğretmenlerin Kendini İșe Verememelerinin Okul Paydaşları (Velilerle) ile İlgili Nedenleri}

Öğretmenlerin kendini işe verememelerinin velilerle ile ilgili nedenlerine ilişkin katılımcı görüşlerinin analizi sonucu elde edilen tema ve bu temaya ilişkin kodlar Tablo 12'de verilmiştir.

Tablo 12.Öğretmenlerin Kendini İşe Verememelerinin Velilerile İlgili Nedenleri

\begin{tabular}{|c|c|c|}
\hline \multirow{17}{*}{ 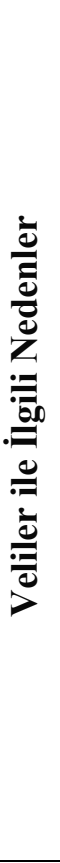 } & & Frekans \\
\hline & Eğitime gerekli önemi vermemeleri, ilgisizlikleri & 13 \\
\hline & Öğrencilerle ilgili sorumlulukları öğretmene yüklemeleri & 7 \\
\hline & Öğretmenin işine müdahaleci ve bilmiș tavırları & 5 \\
\hline & $\begin{array}{l}\text { Sorunları öğretmenle konuşmak yerine şikâyet yolunu tercih } \\
\text { etmeleri }\end{array}$ & 5 \\
\hline & Öğretmene saygı duymamaları & 4 \\
\hline & $\begin{array}{l}\text { Çocukların hatalarını göremeyecek kadar onlara düşkün } \\
\text { olmaları }\end{array}$ & 3 \\
\hline & Bilinçsiz olmaları & 3 \\
\hline & Empati kurmamaları & 2 \\
\hline & Sürekli olarak sorunları ön plana cıkarmaları & 1 \\
\hline & Öğretmene değer vermemeleri & 1 \\
\hline & Öğretmen üzerinde baskı kurmaları & 1 \\
\hline & Öğretmene karşı yargılayıcı tutum sergilemeleri & 1 \\
\hline & Hakaret ve darp içeren söylem ve hareketleri & 1 \\
\hline & Bencil olmalar1 & 1 \\
\hline & Öğretmen önerilerini dikkate almamaları & 1 \\
\hline & Toplam & 49 \\
\hline
\end{tabular}

Tablo 12 incelendiğinde kendini işe verememenin velilerle ilgili nedenlerinden en çok ifade edilenlerin; velilerin eğitime gerekli önemi vermemeleri ve ilgisizlikleri, öğrencilerle ilgili sorumlulukları öğretmene yüklemeleri, öğretmenin işine müdahaleci ve bilmiş tavırlar sergilemeleri, sorunları öğretmenle konuşmak yerine şikâyeti tercih etmeleri, öğretmene saygı duymamaları, çocukların hatalarını göremeyecek kadar onlara düşkün olmaları, empati kuramamaları ve bilinçsiz olmaları şeklinde nedenler olduğu görülmektedir. Velilerin öğretmen üzerinde baskı kurmaları, hakaret ve darp içeren söylem ve hareketlerde bulunmaları da kendini işe verememenin velilerle ile ilgili diğer nedenleri olarak ön plana çıkmaktadır. Öğretmenlerin bu konudaki görüşlerine örnek olabilecek bazı ifadeleri aşağıdaki gibidir: 
“Öğretmene işini öğretmesi, hakaret, darp, öğrencisine ilgisizliği.” (Ö3)

"Eğitimle ilgili bütün sorumluluk öğretmeninmiş gibi hareket etmesi, öğretim ile ilgili bir aksaklıkta kendinde ve çocukta herhangi bir eksiklik görmemesi, herkesin, çocuğunun mükemmel olması, öğretmenin önerdiği tavsiyelerin dikkate alınmaması." (Ö4)

"Görsel ve yazılı medyanın olumsuz örneklerinden etkilenip öğretmene yansıyan çirkin tutumlar.” (Ö7)

"Bazı yerlerde veli, öğretmeni emir eri falan zannediyor. Kalıcı öğrenme elbette okul, aile iş birliğiyle mümkün ama bu, öğretmene işini öğretme ya da eğitimi zorlaştıracak garip beklenti ve istekler haline dönüşmemeli.” (Ö17)

"Eğitim sürecinde tüm sorumluluğu öğretmene yükleyen, okuldan mucizeler bekleyen veli profili söz konusu olduğu durumlarda yetersizlik hissedilebilir. İlk eğitimin ailede başladığını unutmadan ve bu konuda desteklerini esirgemeyen veliler sayesinde eğitimin kalitesi artabilmektedir.” (Ö20)

"Anlayışl1, eğitimli, saygıll veliler oldukça öğretmen kendini işine daha çok verir. Öğretmene güvenen veli sayısının çok olması gerekmektedir.” (Ö33)

Öğretmenlerin Kendini İşe Verememelerinin Okul Paydaşları (Diğer Personel) ile İlgili Nedenleri

Öğretmenlerin kendini işe verememelerinin diğer personel ile ilgili nedenlerine ilişkin katılımc1 görüşlerinin analizi sonucu elde edilen tema ve bu temaya ilişkin kodlar Tablo 13'te verilmiştir.

Tablo 13.Öğretmenlerin Kendini İşe Verememelerinin Diğer Personel ile İlgili Nedenleri 
Tablo 13 incelendiğinde kendini işe verememenin diğer personel ile ilgili nedenlerinden en fazla ifade edilenlerin; diğer personelin görevlerini tam olarak yapmamaları ve saygısızlık içeren davranışları şeklinde nedenler olduğu görülmektedir. Diğer personelin okul iklimini bozmaları, laubali davranışları, öğretmenlerin işlerini zorlaştırmaları, kendi aralarındaki çatışmaları, öğrencilere karşı kaba davranışlar sergilemeleri nedenleri de diğer personelle ilgili nedenler olarak belirlenmiştir. Öğretmenlerin bu konudaki söylemlerinden bazıları aşağıdaki gibidir:

"Öğretmenden daha fazla değer verilmesi, laubali davranışlar sergilemeleri." (Ö3)

"Okulda personeller arası çatışma durumlarının sıklıkla yaşanması." (Ö6)

"Hizmetlilerin öğretmenlerden daha rahat olmaları, işi aksatmaları, sınıf temizliklerini yapmamaları ve bunun akabinde velilerin eleştirileri arasına kalan öğretmenler." (Ö7)

"Bazen okula gitmek istemezsin. Çünkü; okul iklimini bir personel bozar mı? Evet hem de nasıl... Çocukların olduğu yere her insan alınmamalı. Öğretmenin, öğrencinin, velinin ruh halini bozabilmekteler." (Ö8)

"Kadrolu müstahdemlerin işin gereğini yerine hakkıyla getirme azminden yoksunlukları ve buna rağmen işine devam edebilmeleri” (Ö14)

"Bu kişiler üzerinde idarenin ve öğretmenlerin etkisinin şunun bunun yakını, bunun yeğeni vs. şeklinde gerekçelerle azaltılması.” (Ö17)

"Bazı çalışan hizmetlilerin öğrencilere kaba davranmaları" (Ö28)

\section{Öğretmenlerin Kendini İșe Verememelerinin Diğer Nedenleri}

Öğretmenlerin kendini işe verememelerinin diğer nedenlerine ilişkin katılımcı görüşlerinin analizi sonucu elde edilen tema ve bu temaya ilişkin kodlar Tablo 14 'te verilmiştir.

Tablo 14.Öğretmenlerin Kendini İşe Verememelerinin Diğer Nedenleri

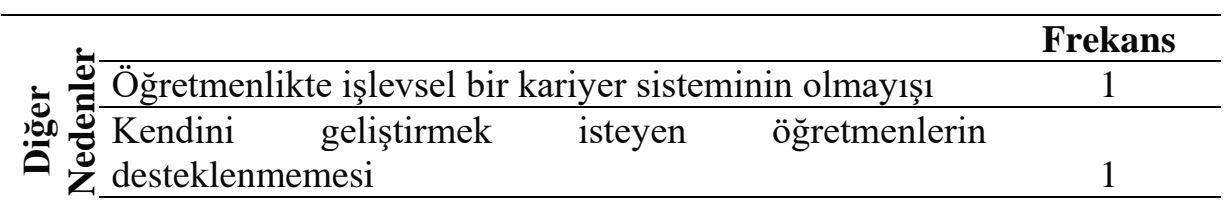




\begin{tabular}{lc}
\hline Yurt içi ve yurt dışı eğitimlere katılamamak & 1 \\
\hline Fiziksel ve ruhsal sağlık problemlerinin yaşanması & 1 \\
\hline $\begin{array}{l}\text { Annelik rollerinin kadın öğretmenlere ayrı bir yük } \\
\text { getirmesi }\end{array}$ & 1 \\
\hline Öğretmen yetiştirme sürecinde yaşanan sorunlar & 1 \\
\hline Mükemmeliyetçilik & 1 \\
\hline Tükenmişlik & 1 \\
\hline Doyumsuzluk & 1 \\
\hline
\end{tabular}

Tablo 14 incelendiğinde kendini işe verememenin diğer nedenlerinin; öğretmenlikte işlevsel bir kariyer sisteminin olmayışı, kendini geliştirmek isteyen öğretmenlerin gerekli desteği bulamamaları, öğretmenlerin yurt içi ve yurt dışı eğitimlere katılma imkânlarının olmaması, öğretmenlerin yaşadığı fiziksel ve ruhsal sağlık problemleri, annelik rolünün kadın öğretmenlere daha fazla yük getirmesi, öğretmen yetiştirme sürecinde yaşanan sorunlar, mükemmeliyetçilik, tükenmişlik ve doyumsuzluk şeklinde nedenler olduğu görülmektedir. Öğretmenlerin bu konudaki görüşleriyle ilgili bazı ifadeleri aşağıdaki gibidir:

"Kendini geliştirmeye çalışan öğretmenlerin (yüksek lisans, kurs vb.) maaşlarında en küçük bir iyileştirmenin bile yapılmaması öğretmenlerin bu konuda isteksiz davranmalarına neden olmaktadır." (Ö4)

“..., tükenmişlik, ..., mükemmeliyetçilik... .” (Ö6)

“... Yurt dış1 eğitim, yurt içi eğitim hiçbirini alamıyoruz. Örneğin; neden üniversitelerimiz bizi takip etmiyor ve düzenli çağırıp yenilikler üzerine eğitime devam etmiyor?” (Ö8)

“..., öğretmenin mesleğinde yükselme imkanının olmaması.” (Ö19)

"Hastalandığımız bazı dönemler verimli olamamaktayız. Fiziksel ve ruhsal sağlık eğitim-öğretimin en önemli unsuru.” (Ö30)

\section{SONUÇ, TARTIŞMA ve ÖNERILER}

Araştırma sonucunda öğretmenlerin kendini işe verememelerinin mesleki bağl1lıkları ve mesleki tutumları ile ilgili nedenlerinden "Kişisel Nedenler" in; öğretmenlik mesleğini sevmeme, yanlış meslek seçiminde bulunmuş olma, öğretmenlik mesleğinin maddi kaygılardan dolayı yapılıyor olması ve üniversite puanının ancak öğretmenlik bölümünü kazanmaya yetmiş olmasından dolayı seçilmiş olması nedenleri olduğu ortaya çıkmışır. Bunun yanı sıra öğretmenlik 
mesleğini zorunluluktan dolayı yapıyor olma, bu mesleği tanımadan seçmiş olma ve öğretmenlik mesleğinin yıpratıcı olması, diğer kişisel nedenler olarak belirlenmiştir. Meslektaşların motivasyon kırıcı tutum ve davranışlarının olması, öğretmenlerin başarılarının ödüllendirilmemesi, üst makamların olumsuz tutum ve davranışlarının olması, yönetimin öğretmenlere değersizlik duygusu yaşatması ve mesleğin başındaki idealistliğin süreç içerisinde hayal kırıklığına dönmesi nedenlerinin öğretmenlerin kendini işe verememelerinin mesleki bağl1lık ve mesleki tutum ile ilgili nedenlerinden "Meslektaş, Okul, Üst Yönetim Kaynaklı Nedenler" olduğu belirlenmiştir. Öğretmenliğin toplumda saygın bir meslek olarak görülmemesi, öğrencilerin/velilerin olumsuz tutum ve davranışlarda bulunmaları, eğitimle bir şeyin değiştirilemeyeceği yönünde öğrenci/veli inancı ve başarısızlığın nedeninin sadece öğretmene bağlanması nedenleri, öğretmenlerin kendini işe verememelerinin mesleki bağlılıklarını ve mesleki tutumlarını olumsuz etkileyen "Aile ve Toplum Kaynaklı Nedenler" olarak ortaya çıkmıştır.

Öğretmenlik mesleğinin tanınmadan, bilinçsizce, sadece zorunluluktan dolayı ve sevilmediği halde seçilmiş olması, öğretmenliğin sadece maddi kaygılardan ve zorunluluktan dolayı yapılıyor olması birey ve toplum açısından ciddi kayıplara yol açabilecektir. Genelde tüm meslek seçimlerinde özelde ise öğretmenlik mesleği seçiminde bireylere istedikleri, sevdikleri ve kendileri için uygun ve doğru olan mesleğin seçimi noktasında ciddi yönlendirmelerin ve bilgilendirmelerin yapılmamış olması bu istenmeyen durumun ortaya çıkmasının nedeni olarak gösterilebilir. Yapılan bazı araştırmalarda öğretmen adaylarının üniversite sınavlarında aldıkları puanların istedikleri bölümlere yetmediği için öğretmenlik bölümlerini tercih ettiklerini göstermektedir (Çermik, Doğan ve Şahin, 2010; Özsoy, Özsoy, Özkara ve Memiş, 2010). Mesleğin isteyerek seçilmeyişi meslek hayatında bir takım olumsuz durumların oluşmasına kaynaklık edebilmektedir. Ertürk ve Aydın'ın (2017) araştırmasına katılan öğretmenler çalışma ortamını sevmeyişini, özgüven eksikliğini, okuldaki mutsuzluğu, başarısızlık duygusunu, yanlış meslek seçimini ve mesleki yetersizlik durumunu iş motivasyonlarını olumsuz etkileyen bireysel kaynaklı durumlar olarak görmektedirler. Bunun yanı sıra öğretmenler yaptıkları işlerin takdir edilmesi, iş ortamının huzurlu olması, iletişim engellerinin olmaması (Çiftçi, 2017), zümre arkadaşlarıyla kurulan olumlu diyaloglar ve öğrenci velilerinin olumlu katkılarını iş motivasyonlarını arttırıcı unsurlar olarak görmekte ve iş hayatındaki başarı ve tatmin olma derecelerinin, çalıştıkları ortamda yaşadıkları eşitlik veya eşitsizliklere bağlı olduğunu ifade etmektedirler (Avşar, 2014). Belirtilen bu nedenlerin aynı zamanda öğretmenlerin mesleğe ve eğitime olan inançlarını düşürücü bir unsur haline gelebileceği ifade edilebilir. Gün (2017) yapmış olduğu araştırma sonucunda öğretmenlerde eğitime olan inanç ile kendini işe verme davranışı arasında doğru orantı bulunduğu sonucuna ulaşmıştır. $\mathrm{Bu}$ araştırma sonucuyla farklı araştırma sonuçları birlikte 
değerlendirildiğinde öğretmenlerin, kendini işe verememelerinin nedenlerinin benzer durumları işaret ettikleri görülmektedir.

Araştırmanın bir diğer sonucuna göre; aile içi sorunların yaşanması, aile içinde iletişimsizliklerin ve huzursuzlukların varlığ 1 , aile bireylerinin ciddi sağlı problemleri yaşamaları, öğretmenlerin çocuklarını bırakılabilecekleri uygun ortam bulmada ve küçük çocuklarının bakımı konusunda zorluklar yaşamaları, öğretmenlerin ailelerine yeterli nitelikte ve nicelikte zaman ayıramamaları, öğretmenin parçalanmış bir aileye sahip olması nedenlerinin öğretmenlerin kendilerini işe verememelerinin aile ile ilgili nedenleri olduğu ortaya çıkmıştır. $\mathrm{Bu}$ nedenlerin yanı sıra öğretmenin evinde bakıma muhtaç birinin var olması ve ailesi içinde yaşanan şiddet de aile ile ilgili öne çıkan diğer nedenler olarak belirlenmiştir. Bu araştırmanın sonucuna benzer olarak Ertürk ve Aydın (2017) tarafından yapılan araştırmaya katılan öğretmenler, ailevi sorunların yanı sıra sağlık sorunlarını iş motivasyonlarını olumsuz etkileyen bireysel kaynaklı durumlar olarak ifade etmişlerdir. Hultell ve Gustavsson (2011) araştırmalarında iş talepleri, iş kaynakları ve özel hayat ile iş arasındaki yayılmanın kendini işe verme üzerindeki büyük bir etkiye sahip olduğu sonucuna ulaşmışlardır. Aydın ise (2019) yapmış olduğu araştırma sonucunda ise iş-aile çatışması azaldıkça kendini işe vermenin artacağ 1 sonucuna ulaşmıştır. Ayrıca olumlu bir iş-aile kültürünün, iş görenlerin iş ve aile alanlarına ait sorumlulukları yerine getirmesi konusunda daha az çatışma yaşamasını sağlayarak, çatışmanın azalmasına paralel biçimde iş görenin kendini işe verme düzeyini arttıracağını belirtmektedir. Sonuç olarak bu ve yapılan farklı araştırma sonuçları; aile hayatının düzenli olması, ailevi sorumlulukların yerine getirilmesi, fiziksel ve mental sağlığın iyi durumda olması gibi unsurların aile-iş dengesinin sağlanmasına katkı sunduğu ve iş görenin kendini işe vermesinde önemli faktörler olduğunu göstermektedir.

Araştırmanın bir diğer sonucuna göre öğretmenlerin kendini işe verememelerinin içinde bulunulan ekonomik durum ve mesleğin gelir düzeyi ile ilgili nedenlerin; öğretmenlerin gelirlerinin ihtiyaçlarını karşılayamaması, ülkede yaşanan ekonomik krizler ve pahalılık, öğretmenlerin ek iş yapmak zorunda kalmaları, öğretmenlerin kişisel gelişimleri için kaynak bulamamaları, çocuk ve eş yardımı ödemelerinin yetersiz oluşu, maaşın yetersizliğinden dolayı kaliteli bir yaşam sürülememesi ve öğretmenlerin toplum nazarında ekonomik yönden saygınlıklarının olmaması şeklinde ortaya çıkmıştır. Öğretmenler gelirlerinin düşük olduğunu düşünmekte, bundan dolayı ekonomik problemler yaşamakta ve bu durumun da kendini işe vermelerini olumsuz etkilediğini belirtmektedirler. Bozbayındır'ın (2019) araştırmasına katılan öğretmenler, mesleğin maddi getirisinin az olmasını öğretmenlik mesleğinin statüsünü düşüren en önemli unsurlardan biri olarak görmektedirler. Avşar'ın (2014) yapmış olduğu araştırmaya katılan öğretmenlerin çoğunluğu elde ettikleri gelirin kendilerinin ve ailelerinin temel ekonomik ihtiyaçlarını karşılamadığını ve motivasyonlarını 
olumsuz etkilediğini ifade etmektedirler. Ertürk ve Aydın (2017) tarafindan yapılan araştırmaya katılan öğretmenler de aldıkları maaşın öğretmen beklentilerini karşılamamasını motivasyon azaltıcı bir unsur olarak görmektedirler. Benzer şekilde Aydın, Demirkasımoğlu, Erdemli ve Güner Demir (2019) tarafından yapılan araştırma sonucunda öğretmen ve yöneticiler, kamu hizmeti motivasyonunu düşüren başlıca neden olarak ücret adaletsizliği ve yetersizliğine vurgu yapmaktadırlar. Kızıltepe'nin (2007) araştırmasına katılan öğretmenler iyi bir gelir düzeyine sahip olmanın öğretmenlerin güdülenmelerini arttırıcı bir unsur olduğunu yine aynı şekilde Karabağ Köse, Taş, Küçükçene ve Karataş'ın (2018) araştırmasına katılan yönetici ve öğretmenler de ekonomik etkenlerin motivasyonlarını etkilediğini, maaşların ve özlük haklarının iyileştirilmesini motivasyonlarını arttırıcı unsurlar olduğunu değerlendirmişlerdir. Koçak (2013), üniversitelerde görev yapan akademisyenlere yönelik yapmış olduğu araştırmasında, akademik giderler için desteği olmayan akademisyenlerin kendini işe verme düzeylerinin desteği olanlara göre daha düşük olduğu sonucuna ulaşmıştır. Yapılan araştırmalar ve bu araştırma sonuçları birlikte değerlendirildiğinde ekonomik etkenlerin öğretmenlerin motivasyonlarında olduğu gibi kendini işe vermeleri üzerinde de önemli bir etken olduğu görülmektedir.

Araştırmanın bir diğer sonucuna göre eğitim politikalarının, sisteminin ve mevzuatının sık sık değişmesi, öğretmenlerin siyasal ve politik gelişmelerden duydukları kaygı, ülke sorunlarının yarattı̆̆ 1 umutsuzluk, öğretmen üzerindeki denetim ve kamuoyu baskısı, öğretmen istihdam ve yer değiştirme politikalarındaki yanlışlıklar, siyasi otoritenin öğretmenin yanında olduğunu hissettirmemesi, okullarda bazı gruplara ayrıcalıklı davranılması, öğretmenlerin terör bölgelerinde görev yapıyor olmaları ve Bimer-Cimer uygulamalarının olumsuz yansımaları öğretmenlerin kendilerini işe vermelerini engelleyen ülkedeki siyasal/politik gelişmelerle ilgili nedenler olarak belirlenmiştir. Karabağ Köse, Taş, Küçükçene ve Karataş'ın (2018) araştırmasına katılan öğretmenler sık değişen eğitim politikaları, yetki ve sorumluluk dengesizliği, geleceğe ilişkin belirsizlik, akademik başarı odaklı politikalar, aşırı iş yükü, olumsuz tepkiler ve şikayetler gibi konuların motivasyon düşüren unsurlar olduğunu vurgulamışlardır. Yine Ertürk ve Aydın (2017) tarafından yapılan araştırmaya katılan öğretmenler de yönetmelik değişikliklerinde öğretmen görüşlerine başvurulmaması ve yönetmelik değişikliklerin sıklıkla yapılması gibi unsurları iş motivasyonunu olumsuz olarak etkileyen nedenler olarak değerlendirmişlerdir. Beklenilen sonuçları sağlayıp sağlamadığı tartışılsa da eğitim sistemi içerisindeki güncel ihtiyaçlar beraberinde farklı değişim uygulamalarını ortaya çıkarmaktadır (Çelik ve Atik, 2020). Bu farklı değişim uygulamaları sonucu meydana gelen değişim yorgunluğu da öğretmenlerde moral yitimine sebep olabilmektedir (Limon, 2019). 
Araştırma sonucunda, görev yapılan yerin sosyokültürel ve sosyoekonomik özelliklerinin de kendini işe vermelerini engelleyen nedenler arasında olduğu ortaya çıkmıştır. Görev yapılan yerin düşük sosyoekonomik düzeyi, görev yapılan toplum içinde öğretmenliğin saygınlığının ve öneminin azalmış olması, öğretmene ve eğitime toplumun olumsuz ve ön yargılı bakışı, görevli olunan yerde sosyal ve kültürel etkinlikleri yapacak imkânların yetersiz oluşu, yöre halkının yeniliğe kapalı, bilinçsiz, eğime bakışlarının olumsuz ve eğitimin önemini ve gereğini anlayamamış olmaları, görevli bulunulan yerdeki halkın farklı inanç ve ideolojilere sahip olması, görevli bulunulan yerin gelişmemiş çevre koşullarına sahip olması, öğretmenlerin görev yerlerine uyum problemleri yaşamaları, coğrafi bölgeler arasındaki farklılıklar ve bu yerlerde öğretmenlerin mesleki gelişim imkânlarının olmaması nedenlerinin öğretmenlerin görev yaptıkları yerlerin sosyokültürel ve sosyoekonomik özelliklerinden kaynaklı nedenler olduğu belirlenmiştir. Bu sonuçlar bir bütün olarak değerlendirildiğinde görev yapılan yerdeki düşük sosyoekonomik ve kültürel yapının öğretmenler üzerinde birçok alanda zorlayıcı etkiler oluşturabileceği görülmektedir. Öğretmenler, görev yapılan yerdeki düşük sosyoekonomik ve sosyokültürel çevrenin kendini işe verememelerinin bir nedeni olduğunu düşünmektedirler. Yapılan araştırmalar sosyoekonomik çevrenin öğretmenlerin motivasyonları üzerinde etkili olduğunu (Karabağ Köse, Taş, Küçükçene ve Karataş, 2018), öğretmenler tarafından materyal eksikliği, teknik donanımın yetersiz olması ve okullardaki yardımcı personel eksikliğinin iş motivasyonlarını olumsuz etkileyen durumlar olarak görüldüğünü (Çiftçi, 2017; Ertürk ve Aydın, 2017), ders için kullanılan araç ve gereçlerin zengin olması, okulda modern teknolojik eğitim araçlarının olması, temiz, düzgün ve büyük pencereleri olan bir sınıfta ders verme ve okula ulaşımın kolay olması gibi nedenlerin öğretmenleri güdüleyici faktörler olarak değerlendirildiğini göstermektedir (Kızlltepe, 2007). Kendini işe vermeyle ilgili yapılan araştırmalarda da benzer sonuçların ortaya çıktığı görülmektedir. Simbula, Guglielmi ve Schaufeli (2011) zengin kaynaklı çevrenin öğretmenin kendini işe vermesinde önemli bir etken olduğunu benzer şekilde Schweitzer (2014) iş ile ilgili kaynaklara sahip olmanın kendini işe vermeyi artıran en güçlü etken olduğu tespit etmişlerdir. Sonuç olarak sosyoekonomik ve sosyokültürel çevrenin oluşturduğu dezavantajlı durumların öğretmenlerin kendini işe verme olumsuz etkileyeceği ifade edilebilir.

Araştırmanın bir diğer sonucuna göre toplumun eğitime/öğretmene bakışı da öğretmenlerin kendini işe verememelerinin bir nedeni olduğu ortaya çıkmıştır. Eğitimin ve öğretmenin toplumdaki saygınlığının azalmış olması, toplum içerisinde öğretmenleri küçük düşürücü söz, tavır ve hareketlerin varlığı, velilerin öğretmenlere karşı yargılayıcı tutumları, toplumun okula bakımevi öğretmene ise bakıcı gözüyle bakması, veli ve öğrencilerin kendi görevlerini yapmadan her şeyi öğretmenden beklemeleri, toplumda öğretmenliğin az çalışıp çok tatil yapan meslek olarak görülmesi, özellikle toplumda eğitimden çok sınav skorlarının 
önemseniyor olması ve toplumun öğretmenliği basite alması bu başlık altında ortaya çıkan nedenler olarak belirlenmiştir. Avşar'ın (2014) yapmış olduğu araştırmaya katılan öğretmenlerin tamamına yakını öğretmenlerin toplum içerisindeki statüsünün hak ettiği yerde olmadığını belirtmişlerdir. Ertürk ve Aydın'ın (2017) araştırmasına katılan öğretmenler de toplumda mesleğe duyulan saygınlığın yok olmasını motivasyonu olumsuz etkileyen bir durum olarak ifade etmişlerdir. Öğretmenler, velilerin eğitime destek ve önem vermelerini kendilerini güdüleyici bir durum olarak görmekte (Kızıltepe, 2007), akademik başarı odaklı politikaların varlığını, velilerin ilgisizliğini, okula aşırı müdahale edilmesini de motivasyon düşürücü nedenler olarak değerlendirmektedirler (Karabağ Köse, Taş, Küçükç̧ene ve Karataş, 2018). Genel olarak değerlendirildiğinde eğitime, okullara ve öğretmenlere olan toplumsal bakış açısındaki yanılgıların öğretmenlerin kendini işe verme davranışını etkileyecek sonuçlar doğurabileceği ifade edilebilir.

Sosyal medya ve diğer iletişim araçlarında öğretmenlerle ilgili aşağılayıcı ve itibarsızlaştırıcı yayınların yapılması, medyada öğretmenlerle ilgili çoğunlukla olumsuz olayların topluma servis edilmesi, öğretmenlerle ilgili medyada çıkan olumsuz haberlerin toplumda öğretmene karşı önyarg1 ve olumsuz alg1 oluşturması, medyada öğretmenliğin şiddet eğilimli bir meslek olarak topluma lanse edilmesi, ayrıca özellikle medyadaki haberlerle öğretmenliğin cinsel tacizle anılması ve yetkililerin topluma öğretmenlerle ilgili olumsuz mesaj vermeleri öğretmenlerin kendilerini işe verememelerinin nedenleri olarak ortaya çıkmıştır. Berkant ve Cömert (2013) araştırmalarında ulusal yayın yapan bazı gazeteleri incelemeleri sonucunda gazetelerdeki eğitimle ilgili haber içeriklerinin genel olarak olumsuz durumları konu edindiğini belirlemişlerdir. Karabağ Köse, Taş, Küçükçene ve Karataş'ın (2018) araştırmasına katılan öğretmenler bu araştırma sonucunda olduğu gibi sanal ortam, sosyal medya ve mesleğin itibarsızlaştırılması gibi konuları motivasyonlarını düşürücü unsurlar olarak değerlendirmişlerdir. Öğretmenler ayrıca medyanın, mesleği olumsuz etkileyen haberler yapmasını öğretmenlik mesleğinin statüsünü olumsuz etkileyen bir durum olarak ifade etmektedirler (Bozbayındır, 2019). Günümüzde sosyal medyanın ve diğer iletişim araçlarının kamuoyu denetiminde önemli bir yere sahip olduğu ancak sosyal medyanın diğer iletişim araçlarından daha bağımsız ve denetlenebilirliği daha zor bir yapıya sahip olduğu belirtilebilir. Tüm örgütler gibi eğitim örgütlerinin de bu sosyal medya içerisinde her yönüyle ele alındığ 1 bilinmektedir. Olumlu içeriklerin yanı sıra öğretmenlik mesleğinin saygınlığını düşüren pek çok konunun mizah konusu yapıldığı, münferit olayların genellendiği, öğretmenlik mesleğinin farklı meslek gruplarıyla kıyaslandığ 1 içeriklere rastlamak mümkündür. $\mathrm{Bu}$ araştırma ve yapılan farklı araştırma sonuçları birlikte değerlendirildiğinde öğretmenlerin sosyal medya ve diğer iletişim araçlarındaki olumsuz yayınlardan etkilendikleri ve bu durumu 
motivasyonlarını ve kendini işe verme düzeylerini düşürücü bir unsur olarak gördükleri ortaya çıkmaktadır.

Araştırma sonucunda MEB ve ilçe/il milli eğitim müdürlüklerinin de uygulamalarıyla öğretmenlerin kendini işe verememelerine neden olabildikleri ortaya çıkmıştır. Üst kademe yöneticilerin öğretmene değer vermemeleri ve öğretmeni korumayarak yalnız bırakmaları, öğretmene çok fazla sorumluluk yüklenmesi, evrak işlerinde yaşanan yoğunluk ve gecikmeler, başarısızlığın faturasının sadece öğretmene kesiliyor olması, adil ve sistematik bir ödüllendirmenin olmaması, yöneticilerin iletişim yetersizlikleri, üst yönetimlerce öğretmenlere görev tanımlarının dışındaki işlerin yaptırılması, alınan kararlarda öğretmen katılımının sağlanamaması, öğretmenlerin yer değiştirmelerinde zorluk yaşamaları hususları MEB ve ilçe/il milli eğitim müdürlükleri kaynaklı, öğretmenlerin kendini işe verememe nedenleri olarak belirlenmiştir.

Araştırmanın bir diğer sonucuna göre öğretmenlerin kendini işe verememelerinin okul idarecileriyle ilgili nedenleri de bulunmaktadır. Okul idarecileri, adaletsiz ve baskıcı tutum ve davranışlar sergilediklerinde, öğretmeni takdir etmediklerinde, iletişim becerilerinde yetersizlik yaşadıklarında, öğretmeni desteklemediklerinde, öğretmenlerle iş birliği kurmadıklarında, yanlı davrandıklarında, idareciliklerinde yasal güce ağırlık verdiklerinde, yeniliğe ve gelişmeye kapalı olduklarında, çözüm odaklı olmadıklarında ve egolarıyla hareket ettiklerinde öğretmenlerin kendini işe verememelerine neden olabilmektedirler. Okul idarecilerinde aidiyet duygusunun olmaması ve çalışanlarında aidiyet duygusu oluşturamamaları, yöneticilik becerilerinin yetersizliği/yokluğu nedenleri de okul yöneticileri ile ilgili, öğretmenlerin kendini işe vermelerini engelleyen nedenler olarak belirlenmiştir.

Araştırma sonucuna göre öğretmenlerin görev yaptıkları kurumlarda görevli diğer öğretmenler de meslektaşlarının kendini işe verememelerine kaynaklık edebilmektedirler. Kurumda görevli öğretmenler arasında yaşanan iletişimsizlik ya da samimi olmayan iletişimin varlığ , kurumda görevine karşı isteksiz olan, eğitim kaygısı taşımayan duyarsız ve işini yapmayan meslektaşların varlığı, işini iyi yapmak isteyen üretken ve çalışkan öğretmenlerin istekliliğinin diğer öğretmenler tarafından kırılarak bu öğretmenlerin küçümsenmeleri, öğretmenlerin amaçlar için ortak hareket etmemeleri, öğretmenler arasında yaşanan dedikodu, kıskançlıklar ve gruplaşmalar, kimi öğretmenlerin sorumluluktan kaçınarak sorumluluğu başkalarına yıkmaya çalışmaları, üst yönetimin desteğini almış öğretmenlerin umursamazlıkları, öğretmenlerin mesleki aidiyet hissi yaşamamaları ve empati ve işbirliği duygusundan yoksun olmaları öğretmenlerin kendini işe vermelerine engel olan kurumdaki diğer öğretmenler kaynaklı nedenler olarak ortaya çıkmıştır. 
Araştırmanın bir diğer sonucuna göre öğrencilerde motivasyon, ilgi ve istek eksikliğinin olması, öğrencilerin ahlak dışı ve saygısızlık içeren davranışlarda bulunmaları, sorumsuzluk sergilemeleri ve amaçsız olmaları, öğrencilerin ailelerince desteklenmemeleri, narin ve şımarık yetiştirilmiş olmaları, sınıfta özel eğitim öğrencilerinin varlı̆̆ 1 ve yabancı uyruklu öğrencilerin uyum problemleri yaşamaları, öğretmenlerin kendini işe verememelerinin öğrencilerle ilgili nedenleri olarak belirlenmiştir.

Velilerin eğitime gerekli önemi vermemeleri ve ilgisizlikleri, öğrencileriyle ilgili sorumlulukları öğretmene yüklemeleri, öğretmenin işine müdahale eden bilmiş tavırlar sergilemeleri, sorunları öğretmenle konuşmak yerine şikâyeti tercih etmeleri, öğretmene saygı duymamaları, çocukların hatalarını göremeyecek kadar onlara düşkün olmaları, empati kuramamaları ve bilinçsiz olmaları, öğretmen üzerinde baskı kurmaları ve hakaret ve darp içeren söylem ve eylemlerde bulunmaları, öğretmenlerin kendini işe verememelerinin veliler ile ilgili nedenleri olarak ortaya çıkmıştır.

Araştırma sonucunda öğretmenlerin kendini işe verememelerine diğer personelin de kaynaklık yapabildiği görülmüştür. Diğer personelin görevlerini tam olarak yapmamaları ve öğretmenlere karşı saygısızlık içeren davranışlarda bulunmaları, okulun iklimini bozmaları, laubali davranışlar sergilemeleri, öğretmenlerin işlerini zorlaştırmaları, kendi aralarında çatışmalar yaşamaları, öğrencilere karşı kaba davranışlar sergilemeleri, öğretmenlerin kendini işe verememelerinin diğer personelle ilgili nedenleri olarak belirlenmiştir.

Öğretmenlerin kendini işe verememelerinin nedenlerinden okul paydaşları ile ilgili nedenler bir bütün olarak değerlendirildiğinde tüm paydaşlar açısından öğretmenlerin kendini işe verememelerine kaynaklık eden durumların bulunduğu görülmektedir. Öğretmenlerin okul paydaşları açısından güdülenmelerini ve iş motivasyonlarını etkileyen durumların incelendiği farklı araştırma sonuçlarında da bu araştırma sonuçlarına benzer nedenlerin ortaya çıktığı görülmektedir. Kızıltepe'nin (2007) yapmış olduğu araştırmaya katılan öğretmenler; okulda rahat ve huzurlu bir ortam olması, okul yönetiminin öğretmen ihtiyaçlarına ve beklentilerine kulak vermesi, ilgilenmesi, yardımc1 ve destek olmas1, iyi bir diyalog içerisinde olması, başarı ve gösterilen gayretlerden haberdar olması, ödüllendirmesi ve kişisel problemlere karşı duyarlı olması, diğer öğretmenlerle iyi arkadaşlıklar kurulması, dayanışma ve yardımlaşma içinde olunması, öğrencilerle iyi bir diyalog içinde olunması, öğrencilerin başarılı olmaları, çaba göstermeleri, derslerine iyi çalışmaları, derse katılmaları ve öğretmenlere saygı göstermeleri gibi konuları öğretmenleri güdüleyici faktörler olarak ifade etmişlerdir. Ertürk ve Aydın (2017) ise araştırmalarında öğretmenlerin iş motivasyonlarını azaltan yönetsel, meslektaş, öğrenci ve veli kaynaklı birtakım durumları incelemişlerdir. Araştırma sonucunda öğretmenler; yöneticilerin 
yönetimle ilgili uzmanlık alanlarının olmayışı, okul yöneticilerinin sistem ve yapı odaklı davranması, taraf tutmaları, okul yönetiminin yasal ve zorlayıcı güçlerini sıklıkla kullanmaları, dış güçlerden etkilenmesi, adil davranmamaları, baskı grupları karşısında öğretmeni yalnız bırakmaları, şeffaf, birleştirici olmayışları ve resmi işleri yavaşlatmaları konularını öğretmen motivasyonunu olumsuz etkileyen yönetimsel nedenler olarak belirtmişlerdir. Öğretmenler arası gruplaşma, kıskançlık, bencillik, rekabet, olumsuz eleştiriler, takım ruhunun eksikliği ve iletişim bozuklukları konularını da iş motivasyonunu olumsuz etkileyen meslektaş kaynaklı durumlar olarak vurgulamışlardır. İş motivasyonlarını olumsuz etkileyen öğrenci kaynaklı durumlar olarak ise öğrencilerin planlı çalışmayışı, okuma alışkanlıklarının olmaması, isteksiz olmaları, disiplin sorunu olan öğrencilerin var olması, sınıfta hazır bulunuşluk düzeyi düşük öğrencilerin var olması ve hiperaktif öğrencilerin sinıflarda olması nedenlerini ifade etmişlerdir. Son olarak velilerin çocuk eğitimi konusunda bilinçsiz olmaları, velilerin öğrencinin seviyesi üzerinde başarı beklentileri, velilerin eğitim konusunda öğretmen üzerinde baskı oluşturmaları, öğrenci ile ilgilenmemeleri, öğretmeni uzman olarak görmemeleri, öğretmen isteklerine duyarsız kalmaları ve velilerin okul dışında asılsız söylemlerde bulunmaları konularını öğretmenlerin iş motivasyonunu olumsuz etkileyen veli kaynaklı durumlar olarak değerlendirmişlerdir. Ertürk ve Aydın'ın (2017) araştırmalarında buldukları tüm bu sonuçlarla Kızıltepe'nin (2007) yapmış olduğu araştırma sonuçlarının bu araştırmanın sonuçlarıyla önemli ölçüde örtüştükleri görülmektedir.

Öğretmenlerin kendini işe verememe nedenlerinin önemli bir kısmının örgütsel nedenlerden kaynaklandığı ifade edilebilir. Kendini işe vermeyle ilgili yapılan araştırmalar lider-üye etkileşiminin (Gürler, 2018; Gürbüz, 2015; Kavgac1, 2014; Runhaar, Konermann ve Sanders, 2013), okul ikliminin (İnanır, 2020), örgütsel destek algısının (Köse, 2016; Meriç, Öztürk Çiftci ve Yurtal, 2019) ve örgüt ikliminin (Köse, 2016), örgütsel adaletin (Akdeniz, 2018; Köse ve Uzun, 2018), etik liderlik algısının (Eser, 2018) ve kurumsal desteğin (Oymak, 2015) kendini işe verme üzerinde etkilerinin olduğunu göstermektedir. Ayrıca veli desteğinin de öğretmenlerin kendini işe vermeleri üzerinde önemli bir değişken olduğu sonucu ortaya konulmuştur (Oymak, 2015). Wollard ve Schuk (2011: 433) kendini işe vermeye dönük yapılmış kuramsal ve deneysel araştırmaları incelemeleri sonucunda gerçek kurum kültürü, net beklentiler, kurumsal sosyal sorumluluk, teşvik, geri bildirim, hijyen faktörleri, iş yeri güvenlik algıs1, iş karakteristikleri, iş kontrolü, iş uyumu, liderlik, görevin zorluk derecesi, yönetici beklentileri, yöneticinin öz-yeterliliği, örgütün misyon ve vizyonu, eğitim firsatları, pozitif ve destekleyici örgüt iklimi, yetenekli yönetici ve güçlü yanların kullanımı gibi örgütsel öncüllerin iş görenlerin kendini işe vermeleri üzerinde etkili olduğunu ortaya koymuşlardır. Kendini işe vermeyle ilgili eğitim örgütlerinde yapılmış olan yukarıdaki araştırma sonuçlarının 
Wollard ve Schuk’un (2011) ortaya koyduğu örgütsel öncüllerle benzerlik gösterdiği görülmektedir. Öğretmenlerdeki kendini işe verme davranışı ile okulların etkililiği arasında bir ilişki olduğu (Atcıŏlu ve Köse, 2018) dikkate alındığında örgütsel faktörlerin kendini işe verme davranışı üzerinde belirleyici etkiye sahip oldukları ortaya çıkmaktadır.

Araştırma sonucunda, öğretmenlik mesleğinde işlevsel bir kariyer sisteminin olmayışı, kendini geliştirmek isteyen öğretmenlerin gerekli desteği bulamamaları, öğretmenlerin yurt içi ve yurt dışı eğitimlere katılma imkânlarının olmaması, öğretmenlerin yaşadığı fiziksel ve ruhsal sağlık problemleri, annelik rolünün kadın öğretmenlere daha fazla yük getirmesi, öğretmen yetiştirme sürecinde yaşanan sorunlar, mükemmeliyetçilik, tükenmişlik ve doyumsuzluk durumları öğretmenlerin kendini işe verememelerinin diğer nedenleri olarak ortaya çıkmıştır. Bu araştırma sonucunda olduğu gibi Ertürk ve Aydın (2017) tarafından yapılan araştırma sonucunda da öğretmenler işlevsel bir kariyer basamaklarının olmayışını motivasyonları olumsuz etkileyen bir durum olarak görmektedirler. Karabağ Köse, Taş, Küçükçene ve Karataş’ın (2018) araştırma sonuçları da bu sonuçları destekler niteliktedir. Araştırmada öğretmenler, öğretmen kariyer sisteminin oluşturulması, hizmet içi eğitimlerin artırılması ve mesleki gelişimin desteklenmesi durumlarını motivasyonlarını arttırıcı unsurlar olarak belirtmişlerdir. Ardıç ve Polatcı'nın (2009: 39-40) araştırmalarına göre de örgütsel koşulları iyileştirmek için alınabilecek her türlü önlem kendini işe vermeyi sağlayıcı etkiye sahiptir. Araştırmacılar, kişisel gelişim ve dinlenmeyi önemsemek, çalışma saatlerinde bunlar için yeterli zaman ayırmak, işyerinde sosyal destek amaçlı gruplar oluşturmak, hizmet içi eğitimler planlamak ve kariyer için firsatlar oluşturmak gibi konuların, iş görenlerdeki kendini işe verme davranışını sağlamada örgütlerce uygulanması gereken önemli stratejiler olarak görüldüğünü ifade etmişlerdir. Bu bakımdan öğretmenlerde görev yapılan okulun özelliklerinden kaynaklı oluşan inançların, onların kuruma ilişkin aidiyet ve bağl1lıkları üzerinde etkili olabildiğinin de (Aslan ve Ağıroğlu Bakır, 2014) göz önünde bulundurulması gerekmektedir.

Araştırma sonucunda ortaya çıkan en dikkat çekici nedenlerden biri de tükenmişlik kavramıdır. Yapılan birçok araştırma tükenmişlik ve kendini işe verme arasında negatif yönlü bir ilişkinin olduğunu göstermektedir (Faskhodi ve Siyyari, 2018; Høigaard, Giske ve Sundsli, 2011; Rey, Extremera ve Pena, 2012; Timms, Brough ve Graham, 2012). Weinreich (2014) araştırmasında tükenmişlik yaşayan öğretmenlerin, kendini işe verme düzeyi yüksek olan öğretmenlere göre iş yükünü daha çok bulduklarını belirlemiştir. Tükenmişlik yaşayan öğretmenlerin işlerinden diğer öğretmenlere göre daha az memnun olduklarını ve iş performanslarının diğer öğretmenlerle kıyaslandığında daha düşük olduğunu ortaya koymuştur. Ayrıca öğretmenin yaşadığı tükenmişlik durumu, kendisinin 
olduğu kadar, öğrencilerin, velilerin ve okul ortamındaki diğer personelin de olumsuz etkilenmesine yol açabilecektir (Öztürk ve Yıldızbaş, 2019).

Araştırma sonuçları bir bütün olarak değerlendirildiğinde öğretmenlerin kendini işe verememelerine kaynaklık eden birçok nedenin bulunduğu görülmektedir. $\mathrm{Bu}$ nedenlerin varlığı eğitim örgütlerinin tüm paydaşlarını zamanla artacak oranlarda olumsuz etkileyebilmekte ve örgütsel amaçların gerçekleştirilmesinde örgütleri zafiyete düşürebilmektedir. $\mathrm{Bu}$ bakımdan öğretmenlerin kendini işe verememe nedenlerinin bilinmesi kendini işe verme davranışının sağlanması ve geliştirilmesi noktasında örgütlere önemli katkılar sunabilecektir.

\section{Öneriler}

\section{Uygulayıcılara dönük öneriler}

1. Araştırmanın sonucunda meslektaş, okul ve üst yönetim kaynaklı nedenlerden dolayı öğretmenlerin kendilerini işe veremeyebildikleri ortaya çıkmıştır. Bu bakımdan bütün öğretmenler, meslektaşlarının motivasyonlarını kırıcı tutum ve davranışlardan kaçınmalı, öğretmenler bu konudaki farkındalıklarını artırmalı ve yapılacak farkındalık eğitimleriyle bu konuda daha da bilinçlendirilmelidirler. Üst makamlarca öğretmenlere, değer verildiği hissi yaşatılmalı, idealist öğretmenlerin idealistlikleri üst yönetimler ve diğer öğretmenlerce bir zenginlik olarak görülmeli ve desteklenmelidir.

2. Eğitim sürecinde öğretmenlerin dışında yer alan birçok paydaşın olduğu bu bakımdan eğitimdeki başarısızlıkların sorumluluğunun tek bir paydaş grubuna (öğretmenlere) yüklenemeyeceği, tüm paydaşların bu süreç ve sonuçta az ya da çok belirli oranlarda katkısının olduğu, toplumun tüm bireylerince bilinmelidir. Eğitimle bir şeylerin değiştirilebileceğine olan öğrenci ve veli inancını arttırmak için eğitim kurumlarınca topluma sunulan faydaların arttırılmasına çalışılmalı, elde edilmiş eğitsel faydaların/kazanımların topluma anlatılmasıyla eğitimin işlevselliği hakkında toplum bilgilendirilmeli, böylece eğitimin toplumca daha fazla sahiplenilmesi sağlanmalıdır.

3. Öğretmenlerin yaşadıkları ailevi sorunlar da kendini işe verememelerine neden olmaktadır. Aile kaynaklı problem yaşayan öğretmenlere dönük aile danışmanlık hizmetleri sunularak öğretmenler bu sorunlara karşı desteklenebilir. Yer değiştirmelerde, atamalarda, okul içi, okul dışı görevlendirmelerde öğretmenlerin kendilerinin ya da aile bireylerinin sahip oldukları ciddi sağlı problemleri ve evde bakıma muhtaç olan yakınlarının varlığı durumları göz önüne alınabilir. 
4. Araştırma sonucuna göre öğretmenlerin gelirlerinin ihtiyaçlarını karşılayamadığ 1 ortaya çıkmıştır. Ülkede yaşanan/yaşanacak olan ekonomik krizler ve pahalılık bütün kesimleri etkilediği gibi öğretmenleri de etkilemekte, öğretmenleri ek iş yapmaya zorlamaktadır. Maaşların yetersiz oluşu öğretmenlerin kişisel gelişimleri için kaynak bulamamalarına, kaliteli bir yaşam sürememelerine ve toplum nazarında ekonomik yönden saygınlıklarının azalmasına neden olmaktadır. Bu bakımdan genel bütçeden öğretmen maaşları için ayrılan ödenek arttırılarak öğretmenlerin gelir durumlarında iyileştirmeye gidilebilir.

5. Öğretmenlerin görev yaptıkları sosyokültürel ve sosyoekonomik düzeyi düşük olan yerlerde veya oluşturulacak merkezlerde öğretmenlerin ve yöre halkının katılabileceği sosyal ve kültürel etkinlikler planlanabilir. Görevli bulunulan yerdeki halkın farklı inanç ve ideolojilere sahip olması ile ilgili olarak öğretmenler hizmet öncesinde ve hizmet içinde bilgilendirilebilir/bilinçlendirilebilir. Görev yerine daha kolay uyum sağlayabilmeleri açısından oryantasyon çalışmaları arttırılabilir. Hizmet öncesinde daha yoğun staj yapma imkânı sağlanabilir, stajlar sosyokültürel ve sosyoekonomik düzeyi daha düşük olan yörelerde yaptırılabilir. Dezavantajlı bölgelerde görevli öğretmenlerin mesleki gelişimlerini gerçekleştirebilmeleri için yapılacak planlama ve uygulamalarda, bu bölgelerde görevli öğretmenlere bu anlamda pozitif ayrımcılık yapılabilir.

6. Sosyal medya ve diğer iletişim araçlarında öğretmenlerle ilgili aşağılayıcı ve itibarsızlaştırıcı yayınların yapılması durumu yapılacak yasal düzenlemelerle engellenebilir. Öğretmenlerin gerçekleştirdikleri olumlu çalışmalar ve iyi örnekler topluma sunularak bu geniş kitlenin topluma sunduğu olumlu katk1lar yine bu kitle içerisindeki genele nispeten çok düşük orandaki bir kesimin ortaya koyduğu olumsuzlukların gölgesinden kurtarılabilir.

7. Araştırma sonucunda MEB ve ilçe/il milli eğitim müdürlüklerinin kaynaklık ettikleri birtakım nedenlerin de öğretmenlerin kendini işe verememelerine neden olduğu ortaya çıkmıştır. Bu bakımdan üst kademe yöneticilerince öğretmenlere hak ettikleri değer verilerek, öğretmenler daha fazla desteklenerek, öğretmene işi ve görev tanımı dışında sorumluluklar verilmeyerek, öğretmenlerin asli işlerini yapmalarına engel olacak gereksiz evrak/kırtasiye işleri kaldırılarak, başarıda ve başarısızlıkta sorumluluk ve övünç birlikte paylaşılarak, adil ve sistematik olan, performansa dayalı bir ödüllendirme sistemi kurularak, yöneticilerin iletişim becerileri arttırılarak ya da iletişim becerisine sahip yöneticiler görevlere getirilerek, yerel ve ulusal düzeyde eğitimle ilgili alınacak kararlara öğretmenlerin daha fazla katılımı sağlanarak öğretmenlerin kendini işe verememe durumları aza indirgenebilir. 
8. Kurumlarda görevli öğretmenler aynı kurumdaki meslektaşlarının kendini işe vermelerine engel olacak nedenlere kaynaklık edebilmektedirler. $\mathrm{Bu}$ bakımdan aynı kurumda görevli öğretmenlerden her biri öğretmenler arasında olumlu ve samimi iletişimin tesis edilmesine katkı sunarak, eğitim kaygısını her an yaşayarak, mesleğinde duyarlı ve işini yapmak isteyen üretken insanlara destek olarak, eğitsel amaçlarda birleşerek, dedikodu ve kıskançlik yapmayarak, gruplaşmalara taraf olmayarak, sorumlulukları paylaşarak, adil, empatik ve iş birliğine açık olarak, mesleki aidiyet yaşayarak hem kendinin hem de meslektaşlarının kendini işe vermelerine üst düzeyde katkı sunabilirler. $\mathrm{Bu}$ konuda daha bilinçli, sağ duyulu ve diğerkâm tutum ve davranışlar sergileyebilirler.

9. Okul idarecileri, öğretmenlerin kendini işe verebilmeleri için adaletli ve baskıcı olmayan bir yaklaşım sergilemeli, yapılan iyi işlerde öğretmeni takdir etmeli ve öğretmenlerini desteklemeli, iletişim becerilerini geliştirmeli, yasal güç yerine uzmanlık gücünü ve liderlik becerilerini kullanabilmeli, çözüm odaklı olup yenilik ve değişim yönünden öğretmenlerinden önde olmalı, egolarıly hareket etmemeli, işine karşı aidiyet duygusu beslemeli ve çalışanlarında aidiyet duygusu oluşturmalı, yönetim biliminin uzmanı ve yönetim sanatının sanatkârı olmalıdırlar. Bu bakımdan bu hususları gerçekleştirebilecek liyakatte kişilerin okul yöneticiliklerine getirilmeleri sağlanmalıdır.

10. Velilere, sorunları öncelikle öğretmenle konuşarak çözme bilinci kazandırılmalıdır. Velilerin öğretmen üzerinde baskı kurmalarının, hakaret ve darp içeren söylem ve hareketlerinin karşılığındaki yasal yaptırımlar kararlılıkla uygulanmalıdır.

11. İşlevsel bir kariyer sisteminin oluşturulması, kendini geliştirmek isteyen öğretmenler için gerekli desteğin ilçe/il milli eğitim müdürlüklerince ve MEB tarafından sağlanması, öğretmenlere yurt içi ve yurt dışı eğitimlere katılma imkanları tanınması, annelik rolü de olan kadın öğretmenlere iş ve ev sorumluluklarını yerine getirmede kolaylaştırıcı- pozitif ayrımcılığın yapılması sağlanabilir. Öğretmenlerin tükenmişlik ve doyumsuzluk nedenleri MEB, İlçe/İl milli eğitim müdürlüklerince araştırılıp bu durumları giderici tedbirler alınabilir.

\section{Araştırmacılara dönük öneriler}

1. Araştırma konusu, farklı bölgelerde çalışan öğretmenlerin katılımlarıyla gerçekleştirilebilir.

2. Öğretmenlerin kendini işe verememe nedenlerinin çalışıldığ araştırmaların birlikte inceleneceği bir meta sentez çalışması yapılabilir. 


\section{KAYNAKÇA}

Agyemang, Collins Badu ve Ofei, Samuel Batchison, (2013), “Employee Work Engagement and Organizational Commitment: a Comparative Study of Private and Public Sector Organizations in Ghana", European Journal of Business and Innovation Research, 1 (4), ss. 20-33.

Akdeniz, Ayşe (2018), Eğitim Örgütlerinde Öğretmenlerin Örgütsel Adalet Algıları ile İşle Bütünleşme Algıları Arasındaki İlişki ve Bazı Değişkenlere Göre İncelenmesi, Yüksek Lisans Tezi, Gazi Üniversitesi Eğitim Bilimleri Enstitüsü, Ankara.

Ardıç, Kadir ve Polatcı, Sema (2009), "Tükenmişlik Sendromu ve Madalyonun Öbür Yüzü: İşle Bütünleşme", Erciyes Üniversitesi İktisadi ve İdari Bilimler Fakültesi Dergisi, (32), ss. 21-46.

Aslan, Mahire ve Ağıroğlu Bakır, Aslı (2014), “Öğretmenlerin Okullarındaki Örgütsel Bağlılığa İlişskin Görüşleri”, The Journal of Academic Social Science Studies, (25-I), ss. 189-206.

Atcioğlu, Ersin ve Köse, Akif (2018), "The Relationship Between the Levels of Teachers' and Administrators' Work Engagement and the Effectiveness of the Schools", International Journal of Eurasia Social Sciences, 9 (32), ss. 915-947.

Aydın, Gözde Gülen (2019), Örgütsel Aile Desteğinin İş-Aile Çatışması ve İşle Bütünleşme Üzerindeki Etkisini Açığa Çıkarmaya Yönelik Bir Araştırma, Yüksek Lisans Tezi, Ege Üniversitesi Sosyal Bilimler Enstitüsü, İzmir.

Aydın, İnayet - Demirkasımoğlu, Nihan - Erdemli, Özge - Güner Demir, Tuğba (2019), "Public Service Motivation From the Point of View of Teachers and School Administrators: a Qualitative Study", Pamukkale Üniversitesi Eğitim Fakültesi Dergisi, 47, ss. 167-190.

Avşar, Filiz (2014), İnsan Kaynakları Bakış Açısıyla Sınıf Öğretmenlerinin İş Motivasyonunu Etkileyen Etmenlere İlişkin Görüşleri: Çankaya İlçesinde Bir Uygulama, Yüksek Lisan Tezi, Çankaya Üniversitesi Sosyal Bilimler Enstitüsü, Ankara.

Berkant, Hasan Güner ve Cömert, Muhammed (2013), “Günlük Gazetelerdeki Eğitimle İlgili Haberlerin İncelenmesi”, Kahramanmaraş Sütçü İmam Üniversitesi İktisadi ve İdari Bilimler Fakültesi Dergisi, 3 (2), ss. 25-44. 
Bozbayındır, Fatih (2019), “Öğretmenlik Mesleğinin Statüsünü Etkileyen Unsurların Öğretmen Görüşleri Temelinde İncelenmesi”, Elektronik Sosyal Bilimler Dergisi, 18 (72), ss. 2076-2104.

Çelik, Osman Tayyar ve Atik, Servet (2020), “Öğretmenleri Değişime Hazırlamak: Psikolojik Güçlendirmenin Bireysel Değişime Hazır Olmaya Etkisi”, Çukurova Üniversitesi Eğitim Fakültesi Dergisi, 49 (1), ss.73-97.

Çermik, Hülya - Doğan, Birsen - Şahin, Abdurrahman (2010), "Sinıf Öğretmenliği Öğretmen Adaylarının Öğretmenlik Mesleğini Tercih Sebepleri”, Pamukkale Üniversitesi Eğitim Fakültesi Dergisi, 28 (28), ss. 201-212.

Çiftçi, Nurdan (2017), Öğretmenlerin Algılarına Göre Motivasyon Kaynaklarının Belirlenmesi, Yüksek Lisans Tezi, Maltepe Üniversitesi Sosyal Bilimler Enstitüsü, İstanbul.

Demerouti, Evangelia - Bakker, Arnold B. - Nachreiner, Friedhem - Schaufeli, Wilmar B. (2001), “The Job Demands-Resources Model of Burnout”, Journal of Applied Psychology, 86 (3), ss. 499-512.

Eser, İsmail (2018), Öğretmenlerin Etik Liderlik Algısının İşle Bütünleşmeile Olan İlişkisinde Pozitif Psikolojik Sermayenin Aracılık Etkisi, Doktora Tezi, Gaziantep Üniversitesi Eğitim Bilimleri Enstitüsü, Gaziantep.

Ertürk, Ramazan ve Aydın, Bahri (2017), "Öğretmenlerin İş Motivasyonunu Artıran ve Olumsuz Etkileyen Durumların İncelenmesi", Akademik Sosyal Araştırmalar Dergisi, (58), ss. 582-603.

Faskhodi, Arefe Amini ve Siyyari, Masood (2018), "Dimensions of Work Engagement and Teacher Burnout: a Study of Relations among Iranian Efl Teachers", Australian Journal of Teacher Education, 43 (1), ss. 78-93.

Gün, Feyza (2017), "Öğretmenlerin Eğitime İnanma ve İşle Bütünleşme Düzeyleri Arasındaki İlişsinin İncelenmesi", Kuramsal Eğitim Bilim Dergisi, 10 (4), ss. 408-431.

Gündüz, Bülent - Çapri, Burhan - Gökçakan, Zafer (2013), “Mesleki Tükenmişlik, İşle Bütünleşme ve İş Doyumu Arasındaki İlişsilerin İncelenmesi”, Eğitim Bilimleri Araştırmaları Dergisi, 3 (1), ss. 29-49. 
Gürbüz, Duygu (2015), Algılanan Örgüt Kültürü ve Lider Üye Etkileșiminin İşe Adanma Üzerindeki Etkisi, Yüksek Lisans Tezi, Okan Üniversitesi Sosyal Bilimler Enstitüsü, İstanbul.

Gürler, Muhammed (2018), Öğretmenlerin Lider-Üye Etkileşimi ile İşle Bütünleşme İliş̧kisinde Çalışan Sesliliğinin Aracılık Etkisinin İncelenmesi, Doktora Tezi, Anadolu Üniversitesi Eğitim Bilimleri Enstitüsü, Eskişehir.

Hakanen, Jari J. - Bakker, Arnold B. - Schaufeli, Wilmar B. (2006), "Burnout and Work Engagement among Teachers", Journal of School Psychology, (43), ss. 495-513.

Harter, Jame K. - Schmidt, Frank L. - Hayes, Theodore L. (2002), "BusinessUnit-Level Relationship between Employee Satisfaction, Employee Engagement and Business Outcomes: a Meta-Analysis”, Journal of Applied Psychology, 87 (2), ss. 268-279.

Høigaard, Rune - Giske, Rune - Sundsli, Kari (2011), "Newly Qualified Teachers' Work Engagement and Teacher Efficacy İnfluences on Job Satisfaction, Burnout, and the İntention to Quit", European Journal of Teacher Education, 35 (3), ss. 347-357.

Hultell, Daniel ve Gustavsson, Petter (2011), "Factors Affecting Burnout and Work Engagement in Teachers When Entering Employment", Work, 40 (1), ss. 85-98.

İnanır, Batuhan (2020), Öğretmenlerin İşle Bütünleşme Düzeyleri ile Okul İklimi ve Öğretmen Liderliği Arasındaki İlişkilerin İncelenmesi, Yüksek Lisans Tezi, Kastamonu Üniversitesi Sosyal Bilimler Enstitüsü, Kastamonu.

Karabağ Köse, Esra - Taş, Ali - Küçükçene, Mehmet - Karataş, Erdem (2018), "Öğretmen Motivasyonunu Etkileyen Faktörlere İlişkin Yönetici ve Öğretmen Görüşleri Üzerine Karşılaştırmalı Bir İnceleme", Mehmet Akif Ersoy Üniversitesi Eğitim Fakültesi Dergisi , (48), ss. 255-277.

Kavgac1, Hasan (2014), İlköğretim Kurumu Öğretmenlerinin İşle Bütünleşme Düzeylerinin Bireysel ve Örgütsel Değişkenlerle İlişkisisi, Doktora Tezi, Gazi Üniversitesi Eğitim Bilimleri Enstitüsü, Ankara.

Kızıltepe, Zeynep (2007), İlköğretim Okullarındaki Öğretmenlerin Güdülenmelerini Artıran, Etkilemeyen ve Düşüren Ögeler, Boğaziçi Üniversitesi Eğitim Dergisi, 24 (2), ss. 47-61. 
Koçak, Ömer Erdem (2013), The Moderating Effect of Self-Efficacy on the Relationship between Job Resources and Work Engagement, Yüksek Lisans Tezi, Marmara Üniversitesi Sosyal Bilimler Enstitüsü, İstanbul.

Köse, Akif (2016), "The Relationship between Work Engagement Behavior and Perceived Organizational Support and Organizational Climate", Journal Of Education And Practice, 7 (27), ss. 42-52.

Köse, Akif ve Uzun, Mehmet (2018), "Kendini İşe Verme ile Algılanan Örgütsel Adalet Arasındaki İlişki", Kuram ve Uygulamada Eğitim Yönetimi, 24 (3), ss. 483-528.

Limon, İbrahim (2019), Eğitim Örgütlerinde Değişim Yorgunluğu, Eğitim Politikaları Bağlamında Moral Yitimi ve İş Performansı Arasındaki İlişki, Doktora Tezi, Bolu Abant İzzet Baysal Üniversitesi, Bolu.

Maslach, Christina ve Leiter, Michael P. (1997), The Truth about Burnout, Jossey-Bass, San Francisco.

Meriç, Erdal - Öztürk Çiftci, Didem - Yurtal, Filiz (2019), "Algılanan Örgütsel Destek ve İşe Adanmışlık Arasındaki İlişkinin İncelenmesi", Kastamonu Eğitim Dergisi, 27 (1), ss. 65-74.

Mustosmäki, Armi - Anttıla, Timo - Oinas, Tomi (2013), "Engaged or Not? A Comparative Study on Factors Inducing Work Engagement in Call Center and Service Sector Work", Nordic Journal of Working Life Studies, 3 (1), ss. 49-67.

Oymak, Çiğdem (2015), Ortaokul Müdürlerinin Denetim Stilleri, Kurumsal Destek ve Veli Desteği ile Öğretmenlerin İşe Yoğunlaşması Arasındaki İlişkinin İncelenmesi (Bala, Haymana, Şereflikoçhisar Örneği), Yüksek Lisans Tezi, Gazi Üniversitesi Eğitim Bilimleri Enstitüsü, Ankara.

Özkalp, Enver ve Meydan, Bilçin (2015), "Schaufeli ve Bakker Tarafindan Geliştirilmiş Olan İşe Angaje Olma Ölçeğinin Türkçede Güvenilirlik ve Geçerliliğinin Analizi”, İş, Güç Endüstri İlişkileri ve İnsan Kaynakları Dergisi, 17 (3), ss. 4-19.

Öztürk, Sevim ve Yıldızbaş, Yalçın Varol (2019), “Öğretmenlerin Öz Yeterlik İnançları ile Mesleki Tükenmişlik Algıları Arasındaki İlişkinin Analizi”,Tarih Okulu Dergisi, 38, ss. 196-233. 
Özsoy, Gökhan - Özsoy, Sibel - Özkara, Yasin - Memiş, Aysel D. (2010), "Öğretmen Adaylarının Öğretmenlik Mesleğini Tercih Etmelerinde Etkili Olan Faktörler”, İlköğretim Online, 9 (3), ss. 910-921.

Rey, Lourdes - Extremera, Natalio - Pena, Mario (2012), "Burnout and Work Engagement in Teachers: are Sex and Level Taught Important?”, Ansiedad Estrés, 18 (2-3), ss. 119-129.

Runhaar, Piety - Konermann, Judith - Sanders, Karin (2013), “Teachers' Organizational Citizenship Behaviour: Considering the Roles of Their Work Engagement, Autonomy and Leaderemember Exchange”, Teaching And Teacher Education, (30), ss. 99-108.

Saks, Alan M. (2006), “Antecedents and Consequences of Employee Engagement”, Journal of Managerial Psychology, 21 (7), ss. 600-619.

Schaufeli, Wilmar B. (2012), "Work Engagement What do We Know and Where do We Go?”, Romanian Journal of Applied Psychology , 14 (1), ss. 3-10.

Schaufeli, Wilmar B. ve Salanova, Marisa (2007), "Work Engagement: an Emerging Psychological Concept and its İmplications for Organizations", Research in Social Issues in Management, (Ed.: S. W. Gilliland, D. D. Steiner, ve D. P. Skarlicki), Ct: Information Age, Greenwich, ss. 135-177.

Schaufeli, Wilmar B. - Salanova, Marisa - Gonzalez Roma, Vicente - Bakker, Arnold B. (2002), "The Measurement of Engagement and Burnout: a Two Sample Confirmatory Factor Analytic Approach”, Journal of Happiness Studies, (3), ss. 71-92.

Schweitzer, Marie Jolene Catherine (2014), Predictors of Work Engagement among Teachers in Regina and Saskatoon, Master Thesis, University of Regina, Regina, Saskatchewan.

Selçuk, Ziya (2001). Okul Deneyimi ve Uygulama (Öğretmen ve Öğrenci Davranışlarının Gözlenmesi), Nobel, Ankara.

Simbula, Silvia - Guglielmi, Dina - Schaufeli, Wilmar B. (2011). “A ThreeWave Study of Job Resources, Self-Efficacy, and Work Engagement among Italian Schoolteachers', European Journal of Work and Organizational Psychology, 20 (3), ss. 285-304.

Şahinbaş, Furkan (2018), Pozitif Örgütsel Davranış Yaklaşımıyla İşyeri Arkadaşı̆̆ı ve İşe Adanma İlişkisi: Sağlık Çalışanları Üzerine Bir 
Araştırma, Yüksek Lisans Tezi, Hacettepe Üniversitesi Sosyal Bilimler Enstitüsü, Ankara.

Timms, Carolyn - Brough, Paula - Graham, Deborah (2012), "Burnt-Out but Engaged: The Co-Existence of Psychological Burnout and Engagement", Journal of Educational Administration, 50 (3), ss. 327345.

Uzun, Mehmet (2019), Yöneticilerin Kullandıkları Örgütsel Güç Kaynakları ile Öğretmenlerin Kendini İşe Vermeleri Arasındaki İlişki (Kahramanmaraş İli Örneği), Yüksek Lisans Tezi, Kahramanmaraş Sütçü İmam Üniversitesi, Sosyal Bilimler Enstitüsü, Kahramanmaraş.

Weinreich, Tobias (2014), Burnout and Work Engagement among Elementary Teachers: are There Differences Among Teachers?, Bachelor Thesis, University Twente, Enschede, Netherland.

Wollard, Karen Kelly ve Shuck, Brad (2011), “Antecedents to Employee Engagement: a Structured Review of The Literature”, Advances İn Developing Human Resources, 13 (4), ss. 429-446.

Yıldırım, Ali ve Şimşek, Hasan (2011),Sosyal Bilimlerde Nitel Araştırma Yöntemleri, Seçkin Yayıncılık, Ankara. 